\title{
A novel approach to modelling the bond characteristics between CFRP fabrics and steel plate joints under quasi-static tensile loads
}

Hemad Hamedi ( $\square$ hamedi.hemad@gmail.com )

Islamic Azad University

ATA Kamyabi-Gol

\section{Research Article}

Keywords: Double strap joints, Failure load prediction, Steel, CFRP, non-linear Lagrange stress method

Posted Date: August 16th, 2021

DOI: https://doi.org/10.21203/rs.3.rs-444523/v1

License: (c) (1) This work is licensed under a Creative Commons Attribution 4.0 International License. Read Full License

Version of Record: A version of this preprint was published at The International Journal of Advanced Manufacturing Technology on July 19th, 2021. See the published version at https://doi.org/10.1007/s00170-021-07714-y. 


\section{Abstract}

Carbon fiber reinforced polymer (CFRP) materials have been effectively used as externally bonded sheets to repair damaged steel structures such as airplanes and ships. In this study, a series of double strap joints with different bonding lengths are considered and examined to experimentally and theoretically assess the effective bond length. Various models exist in the literature which are used to predict the strength of steel and CFRP joints under various loading conditions. Non-linear Lagrange stress method (NLS) which is a novel stress-based method for predicting the failure load values is presented for the first time. This approach is based on 2D and 3D linear elastic finite element analysis. Relying only on two experimental tests, the new approach proposed here can quickly and easily predict the failure load in steel/CFRP samples. In this methodology, it is assumed that the adhesive joint will fail as the normal stress along the adhesive mid-line reaches a predetermined value at a critical distance. In addition, experimental data on steel/CFRP joints gathered from the literature are compared to predictions using the NLS method. It was found that results from the theoretical predictions (NLS) were in good agreement with experimental tests conducted on double strap joints. It was also revealed that the average accuracy of the NLS method is superior to other methods such as cohesive zone model and Hart-Smith. The results revealed that under the best conditions, the NLS model is 5 times more accurate than existing models.

\subsection{Introduction}

Polymeric composite materials (PMC) show superior properties such as high specific strength and stiffness making them versatile materials with various applications in military, civilian aircrafts, space, and automobile industries. PMCs can also be used to improve the life expectancy and load carrying capacities of compromised steel components. For example, carbon fiber reinforced polymer (CFRP) laminates can be applied in retrofitting of steel structures instead of conventional mechanical fasteners due to their light weight and low-cost advantages. Recent studies have shown that the use of CFRP offers an excellent alternative method for repairing deteriorated structures [1-7]. The main application of CFRP laminates is to make structures lighter while maintaining their integrity and strength [8]. For instance, 43\% of metal structures in the Boeing 787 aircraft have been replaced by CFRP laminates [9]. This highlights the importance of a suitable failure predictive approach to design steel/composite bonded joints [10,11]. The discontinuity of reinforcing fibers at joint interfaces can only be overcome by either using adhesive joints or rivet joints to form structural joints in many applications [12-16]. Traditional mechanical fastening approaches cannot be used with PMCs because of the introduction of local stress concentrations in and around the joints [17].

The failure mechanisms in steel/CFRP adhesive bonded joints directly affects the operational life of the components. There is a hand full of various criteria in the literature used in predicting the failure load of adhesively bonded joints. The majority of the available failure criteria are based on stress, strain or energy condition in the bond layer [18-25]. Typically, shear stress and normal stress (also known as peel stress) values are considered as key parameters in failure assessment of steel/CFRP adhesive bonded 
Critical energy as a common failure approach was utilized for double strap joints (DSJ) by some researchers [26, 27]. Hashin's variational method has been improved by Chalkley and Rose [28] and Barroso et al. [29] went even further by including the stress singularity effects to evaluate 4 failures in double lap joints. In a similar study, Lee et al. used an experimental approach to obtain the joint strength and the failure modes in steel and GFRP bonded DSJs [30]. A number of experimentally driven research has focused on investigating the strength of CFRP and steel DSJs. The influence of several parameters on the joint strength has been studied in these experimentally driven approaches (e.g. [31-39]). The bond strength and fatigue crack propagation between steel/FRP sheets has been studied by Zhao et al. studied [40]. Mohee et al. [41] have recently reviewed various aspects of CFRP joints including strength, failure modes, performance and design parameters. The strength of the bond between steel coupons and CFRP strips was studied using a series of DSJs by Fawzia et. al. [42]. The researchers modified the Hart-smith model and predicted the failure load in steel/CFRP DSJs and obtained reasonable results when compared to experimental data.

Until now, many approaches have been proposed to analyze the behavior of steel components strengthened with CFRP patches [43-47], including nonlinear theory [48], digital image correlation (DIC) [49-52], extended finite element method (XFEM) [53, 54] and cohesive zone model (CZM) [55-58].

Adhesive joining of composite-to-metal structures is faced with numerous challenges including the potential for debonding at the adhesive/substrate interface, difficulty in processing, such as achieving a uniform bond line thickness as well as complex surface preparation and tooling, and susceptibility of the joint to creep [52]. As a result, several studies have been performed to investigate the failure behavior of adhesive joints [53-58]. Extensive research has been conducted on the bond behavior between patching systems and steel under static loading [59-62], fatigue loading [63], large deformation cyclic loading [64] and environmental effect $[65,66]$.

Many steel structures deteriorate over time due to environmental corrosion, creep, and changes in their use and hence, need to be strengthened to resist the new loads to which they are subjected to. Static tensile loading is the most common type of load on structures such as steel bridges and buildings [60]. The bond between the CFRP composite and steel is a key issue in CFRP strengthening of aging steel structures; the use of an appropriate type of adhesive results in an acceptable bond.

The Lagrange method of optimization is a well-established mathematical solution algorithm technique that is used for solving constrained optimization problems. Most optimization problems consist of a nonlinear objective function and one or more linear or nonlinear constraint equations. In this method, the constraints as multiples of a Lagrange multiplier, are subtracted from the objective function until the optimal objective function is obtained [75].

In this paper the bond characteristics between CFRP laminate and steel members under quasi-static loading are investigated experimentally and theoretically in a series of DSJs. The presented criterion is based on normal (peel) stress along the midplane of the adhesive layer. In order to validate the presented Loading [MathJax]/jax/output/CommonHTML/fonts/TeX/fontdata.js with six series of experimental data reported in 
the literature $[67,68]$ on DSJs. The aim of this research paper is to predict the failure loads of experimentally tested joints using a newly proposed failure predictive model, namely the non-linear Lagrange stress (NLS) method.

\subsection{Materials And Experimental Procedure}

A schematic representation of the geometry of the test samples used in this research are presented in Fig. 1. DSJs made from grade 300 steel sheets and a single ply of unidirectional normal modulus CFRP sheet on each side of the joints were fabricated with different bonding lengths (Fig. 2). The CFRP sheets were placed with the fibers aligned in the direction of the tensile load. The normal modulus of CFRP was used in this study. Two different size of steel sections $(120 \mathrm{~mm} \times 30 \mathrm{~mm}$ and $160 \mathrm{~mm} \times 40 \mathrm{~mm})$ were used to investigate the effect of steel section size on the bond properties. UHU Endfest 300 was used as adhesive to bond the CFRP to the steel members. The selection of the adhesive was done based on recommendations from industrial practitioners. The mechanical properties of the CFRPs required in the finite element simulations were obtained from the manufacturer's data sheet. UHU® Plus Endfest 300 adhesive (UHU, Buehl, Germany) with a mixing ratio of binder to hardener equal to 2:1 was used for bonding the components [69]. The length, width and thickness of the steel sheets were $L_{\text {sub }}=160 \mathrm{~mm}, W$ $=40 \mathrm{~mm}, t_{\text {sub }}=3 \mathrm{~mm}$, and $L_{\text {sub }}=120 \mathrm{~mm}, W=40 \mathrm{~mm}, t_{\text {sub }}=3 \mathrm{~mm}$, respectively. Each CFRP layer was $0.176 \mathrm{~mm}$ in thickness, while the adhesive was $0.5 \mathrm{~mm}$ thick. Separate tensile tests were conducted on the steel plates (ASTM E8) [71] and adhesive material (ASTM D638) [70, 72] in order to obtain the corresponding mechanical properties under tensile loading (displayed in Table 1). Bulk specimens were prepared from adhesives, and then the stress-strain $(\sigma-\varepsilon)$ behaviors of the adhesive was determined from bulk dumb-bell shaped specimens tested under the conditions specified. The bonding length $L_{1}$ was always kept less than $L_{2}\left(L_{2}=L_{1}+30 \mathrm{~mm}\right)$ to ensure that the failure only occurred on the $L_{1}$ side of the steel sheets (Fig. 1).

The steel sheets were grit blasted to remove any traces of dust, paint, oil and any other contaminants in the bond region ensuring a reliable contact between the adhesive and steel. The bond region was then wiped with acetone before the adhesive was applied to ensure a chemically active surface was obtained. The DSJs were cured for $45 \mathrm{~min}$ at $70^{\circ} \mathrm{C}$ after the application of the adhesive glue. The coupons were then post-cured for 7 days at room temperature (at $25^{\circ} \mathrm{C}$ ).

Table 1

Mechanical properties of materials used for experiments.

\begin{tabular}{|c|c|c|c|}
\hline Properties & Steel plates & Adhesive & CFRP sheets * \\
\hline Tensile modulus (GPa) & 203 & 2.1 & 200 \\
\hline Poisson's ratio & 0.25 & 0.35 & 0.28 \\
\hline Ultimate strength (MPa) & 520 & 39 & 1900 \\
\hline
\end{tabular}

Page 4/30 
Different bonding lengths of $L_{1}=10,20,30,40,50,60 \mathrm{~mm}$ were considered for experiments. At least three test coupons were tested for each mentioned bond length. A universal tensile testing machine (Instron ElectroPulsTM E10000, Norwood, MA, United States) was used for the tensile experiments under quasistatic loading. The load-displacement curves were obtained with a constant strain rate of $2 \mathrm{~mm} / \mathrm{min}$. The average value of the three tests was used in all of the numerical calculations.

Two steel sections were used as $A=120 \times 40 \mathrm{~mm}$ and $B=160 \times 40 \mathrm{~mm}$ to investigate the effect of steel section size on the bond properties. The steel/CFRP DSJs with various bonding lengths before and after the tensile tests are shown in Figure 2.

The details of each experiment (i.e., the dimensions of the DSJs and the corresponding failure loads) is presented in Table 2. As is shown in Table 2, three experimental tests, namely $\boldsymbol{P}_{\mathbf{1}}, \boldsymbol{P}_{\mathbf{2}}$ and $\boldsymbol{P}_{\mathbf{3}}$ are carried out for each bonding length to have better accuracy. The average failure load for each set of tests is reported as Pavg.

Table 2: Details of experimental failure loads for the tested double strap joints (DSJs). 


\begin{tabular}{|c|c|c|c|c|c|c|}
\hline Specimen label & $L_{1}(\mathrm{~mm})$ & $L_{2}(\mathrm{~mm})$ & $P_{1}(\mathrm{kN})$ & $P_{2}(\mathrm{kN})$ & $P_{3}(\mathrm{kN})$ & $\mathbf{P}_{\mathrm{avg}}(\mathrm{kN})$ \\
\hline A & 10 & 40 & 10.5 & 9.7 & 9.9 & 10.03 \\
\hline A & 20 & 50 & 14.1 & 14.3 & 14.7 & 14.36 \\
\hline A & 30 & 60 & 14.8 & 14.6 & 13.8 & 14.4 \\
\hline A & 40 & 70 & 14.5 & 14.3 & 13.7 & 14.16 \\
\hline A & 50 & 80 & 13.9 & 14.7 & 15.1 & 14.56 \\
\hline $\mathrm{A}$ & 60 & 90 & 14.6 & 14.9 & 15.2 & 14.9 \\
\hline B & 10 & 40 & 12.2 & 12.9 & 13.2 & 12.8 \\
\hline B & 20 & 50 & 17.8 & 18.1 & 18.9 & 18.3 \\
\hline B & 30 & 60 & 20.1 & 20.5 & 21.2 & 20.6 \\
\hline B & 40 & 70 & 21.8 & 20.9 & 20.5 & 21.1 \\
\hline B & 50 & 80 & 22.0 & 21.2 & 20.9 & 21.4 \\
\hline B & 60 & 90 & 20.5 & 21.8 & 20.4 & 20.9 \\
\hline
\end{tabular}

\subsection{Finite Element Analysis}

This section is dedicated to evaluating the failure of the DSJs using the elastic behavior of the joints. Finite element analysis is performed on the DSJs in order to predict the failure loads and to obtain the stress distribution across the adhesive mid-plane in the 2D model of the specimens. Only half of each specimen was modeled due to the symmetry of the joints, (see Fig. 4). The finite element program Dassault System ABAQUS-CAE-6.13 (NTNU, Trondheim, Norway) with the CPE8R element type was utilized to enable faster calculations. This element type is an eight-node, biquadratic plane strain quadrilateral element with reduced integration for 2D simulations. 3D finite element analysis was carried out for comparing results with an 8-node three-dimensional cohesive element (COH3D8) [67]. This 3D finite element analysis is strongly recommended by the ABAQUS user manual in modelling two bodies connected by adhesive [73]. The boundary conditions and the applied load in the finite element models are shown in Fig. 4. The same element type was used for finite element modelling of the adhesive joints. A mesh convergence study was undertaken in order to ensure that the proper size of elements was used

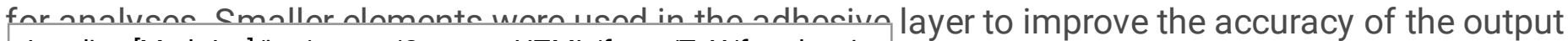
Loading [MathJax]/jax/output/CommonHTML/fonts/TeX/fontdata.js 
results. The mesh pattern used in this research for modelling DSJs is shown in Fig. 5. Also, as seen in Fig. 3, the load-displacement curve is linear up to the final fracture which takes place suddenly with no effective plastic deformation in the adhesive layer. Therefore, the linear elastic assumption is reasonable for failure load prediction in the DSJs. An assumption of linear elastic behavior is typical for most of the structural adhesives which behave predominantly in a linear manner until the final failure [74].

\subsection{Failure Load Prediction}

The effective bonding length of the DSJs should be calculated prior to failure load predictions. According to the data related to adhesive joints in the literature, increasing the bonding length results in a higher load bearing capacity. However, for the adhesive joints with the bonding lengths greater than a specific value, the failure load would remain the same. This critical bonding length is called the "effective bonding length", $L_{\text {eff }}$.

A simple method of obtaining $L_{\text {eff }}$ using $2 \mathrm{D}$ and $3 \mathrm{D}$ linear elastic finite element analysis is proposed here. One major advantage of the proposed methodology is that only the Poisson's ratio and elastic modulus are required to calculate the effective bonding length. Therefore, finite element models of DSJs with different bonding lengths are analyzed under a constant statically applied stress. The longitudinal stress variation along the adhesive mid-plane should be exported for each bonding length (Figs. 6 and 7), and then the value of the first peak in the longitudinal stress curve should be recorded as the critical stress $\sigma_{\mathrm{cr}}$. The corresponding critical longitudinal stress values for the rest of the joints is then obtained in a similar manner. Comparing the critical longitudinal stress values for different bonding lengths reveals the effective bonding length (Fig. 8) as the value where the critical longitudinal stress remains constant with further increase in bonding length (Fig. 8). In the next subsection, the NLS method is described in order to directly determine the value of failure strength and the effective bond length before performing any other experiments.

\subsection{Calculating the Effective Bond Length using the NLS Method}

The joint with $10 \mathrm{~mm}$ bonding length was selected as the reference joint in this study (first experimental test). The applied axial tensile stress can be any value. This load is applied to the joint and the variation of longitudinal stress along the adhesive layer is obtained. $1200 \mathrm{MPa}$ was chosen as the axial tensile load in this study. The first positive peak stress from the bond line edge was considered as the critical longitudinal stress $\sigma_{\mathrm{cr}}$ and it was equal to $10.61 \mathrm{MPa}$ for the reference joint. Selecting a key parameter in a failure method must be done in a way that it is consistent with the detected failure mechanism in the tested joints. Longitudinal stress along the adhesive mid-plane was considered as the key parameter in the failure analysis based on the CFRP rupture and delamination failure mechanisms due to longitudinal stresses at the junction of steel components. 
A similar procedure was followed for the rest of the joints $\left(L_{1}=20,30,40,50\right.$ and $\left.60 \mathrm{~mm}\right)$. The value of critical longitudinal stresses (i.e., first peak value in the longitudinal stress variation along the bond length) for all joints were obtained from elastic analyses. The longitudinal stress distribution along the path defined in the mid-plane of the adhesive layer for the other joints of the present experimental series are shown in Figs. 6 and 7. The variation of critical longitudinal stresses for different bonding lengths are illustrated in Fig. 8. As can be seen from Fig. 8, the bonding length of $L_{1}=30 \mathrm{~mm}$ is the effective bonding length and for higher bonding lengths the longitudinal stress remains constant.

\subsection{Obtaining Theoretical Failure Loads using the NLS Method}

Equation (1) is proposed to obtain the failure loads of the joints. This equation includes a nonlinear piece for bonding lengths smaller than $L_{\text {eff }}$ and a constant piece for DSJs with bonding lengths greater than $L_{\text {eff }}$

$$
P_{\text {Theor }}=\left\{\begin{array}{c}
\text { Lagrange }(x, \text { Pointx }, \text { Pointy }) \quad 0<L_{1}<L_{\text {eff }} \\
F^{*} \quad L_{\text {eff }} \leq L_{1}
\end{array}\right.
$$

where $F^{*}$ is the experimental failure load of adhesive joints with the effective bonding length. The Lagrange function in Equation (1) is based on MATLAB's@ internal Lagrange interpolation function. According to this approach, the failure loads of DSJs with different bonding lengths can be predicted by only testing two joints. Considering any of the tested DSJs with bonding lengths greater than $L_{\text {eff }}$ as the reference joints for failure load prediction, results in the theoretical predictions presented in Table 3 and Figure 9. Good agreement is seen between the NLS predictions and the experimental results.

Table 3: Dimensions of the adhesive joints and details of experimental and theoretical failure loads for the tested DSJs. 


\begin{tabular}{llllll} 
Series & $\begin{array}{l}\text { Bonding } \\
\text { Length, L1 }\end{array}$ & $\begin{array}{l}\text { Bonding } \\
\text { Length, L2 }\end{array}$ & $\begin{array}{l}\text { Experimental failure load, } \\
\mathbf{P}_{\text {Exp. }}(\mathbf{k N})\end{array}$ & $\begin{array}{l}\text { Theoretical failure load, } \\
\mathbf{P}_{\text {Thoor. }}(\mathbf{k N})\end{array}$ & $\boldsymbol{P}_{\text {Theor }} / \boldsymbol{P}_{\text {Exp. }}$. \\
\hline A & 10 & 40 & 10.03 & 10.03 & 1 \\
\hline A & 20 & 50 & 14.36 & 12.2 & 1 \\
\hline A & 30 & 60 & 14.4 & 14.4 & 1.01 \\
\hline A & 40 & 70 & 14.16 & 14.4 & 0.95 \\
\hline A & 50 & 80 & 14.56 & 14.4 & 0.96 \\
\hline A & 60 & 90 & 14.9 & 14.4 & 1 \\
\hline B & 10 & 40 & 12.76 & 12.76 & 0.91 \\
\hline B & 20 & 50 & 18.26 & 16.68 & 1 \\
\hline B & 30 & 60 & 20.6 & 20.6 & 0.96 \\
\hline B & 40 & 70 & 21.06 & 20.6 & 0.96 \\
\hline B & 50 & 80 & 21.38 & 20.6 & 0.96 \\
\hline B & 60 & 90 & 20.9 & 20.6 & 1 \\
\hline
\end{tabular}

For further validation, the proposed method was used to predict the failure loads of six series of DSJs which have been reported in previous experimental studies by Al-Zubaidy et al. [68] in 2D simulation and Al-Mosawe et al. [67] in 3D simulation.

Al-Zubaidy et al. [68] conducted experiments on DSJs of width $50 \mathrm{~mm}$ and bonding lengths of $L_{1}=10,20$, $30,40,50,60,70,80,90$, and $100 \mathrm{~mm}$. For the experimental data series $\mathrm{C}$, one layer of CFRP sheet was bonded on each side of the joints. For the experimental data series $D$, three layers of CFRP sheets were bonded on each side of the adhesive joints. MBrace saturant epoxy adhesive was used for joining the CFRP sheets together and also joining them to the steel plates. Table 4 presents the mechanical properties of the tested joints [68]. In order to simplify the numerical modeling, the three layers of CFRP and two layers of adhesive between them in series $D$ were considered as a single part having an equivalent tensile modulus calculated as follows [71]: 


$$
E_{e q}=E_{a d h} * t_{\frac{a d h}{}+E_{C F R P}} * t_{C F R P}
$$

where $\mathrm{E}_{\text {eq }}$ is the equivalent modulus of the CFRP/adhesive layer, $\mathrm{E}_{\mathrm{adh}}$ and $\mathrm{E}_{\mathrm{CFRP}}$ are the tensile modulus of adhesive layer and CFRP sheets, respectively. The terms $t_{a d h}$ and $t_{C F R P}$ signify the total bondline thickness and the thickness of the CFRP layers. Table 5 summarizes the values of the failure load, obtained experimentally from the tensile quasi-static tests on the DSJ specimens and numerically by means of the 2D finite element analyses based on the NLS method. The discrepancies between the results are also included in Table 5.

Figure 10 shows the critical longitudinal stress as a function of bonding length for the joints in series $C$ and series $D$. According to the plateaus in Figure 10, the effective bonding lengths in series $C$ and $D$ are 30 and $40 \mathrm{~mm}$, respectively. Using these effective bonding lengths and considering one of the joints $(L>$ $L_{\text {eff }}$ ) as the reference joint, the failure loads of the remaining joints were estimated using the NLS method. A comparison between the NLS predictions and the experimental results is illustrated in Figure 11. A good correlation is seen between the experimental data and NLS estimates for failure loads in the tested DSJs.

Table 4

Mechanical properties of materials used for joints series C and D Al-Zubaidy et al. [68].

\begin{tabular}{|lll|}
\hline Material property & Series C & Series D \\
\hline Steel length $(\mathrm{mm})$ & 210 & 210 \\
\hline Steel cross-section $(\mathrm{mm})$ & $50 \star 5$ & $50 \star 5$ \\
\hline Steel modulus $(\mathrm{GPa})$ & 203 & 203 \\
\hline Steel poisson's ratio & 0.25 & 0.25 \\
\hline CFRP cross-section $(\mathrm{mm})$ & $50 \star 0.176$ & $50 \star 1.588$ \\
\hline CFRP modulus $(\mathrm{GPa})$ & 205 & 52.778 \\
\hline CFRP poisson's ratio & 0.28 & 0.28 \\
\hline Adhesive modulus $(\mathrm{GPa})$ & 2.229 & 2.229 \\
\hline Adhesive cross-section $(\mathrm{mm})$ & $50 \star 0.53$ & $50 \star 0.53$ \\
\hline Adhesive poisson's ratio & 0.35 & 0.35 \\
\hline Bond length range $(\mathrm{mm})$ & $10-100$ & $10-100$ \\
\hline
\end{tabular}

Table 5: Details of experimental results with theoretical failure load predictions for the joints series C and D [68] 


\begin{tabular}{|c|c|c|c|c|c|}
\hline Series & $\begin{array}{l}\text { Bonding } \\
\text { Length, L1 }\end{array}$ & $\begin{array}{l}\text { Bonding } \\
\text { Length, L2 }\end{array}$ & $\begin{array}{l}\text { Experimental Failure Load, } \\
\mathbf{P}_{\text {Exp. }}(\mathrm{kN})\end{array}$ & $\begin{array}{l}\text { Theoretical Failure Load, } \\
\mathrm{P}_{\text {Theor. }}(\mathrm{kN})\end{array}$ & $P_{\text {Theor }} / P_{E_{x x}}$ \\
\hline $\mathrm{C}$ & 10 & 80 & 19.3 & 19.3 & 1 \\
\hline C & 20 & 80 & 32.6 & 30.45 & 0.93 \\
\hline C & 30 & 80 & 41.6 & 41.6 & 1 \\
\hline C & 40 & 80 & 40.6 & 41.6 & 1.02 \\
\hline C & 50 & 80 & 41.0 & 41.6 & 1.01 \\
\hline C & 60 & 80 & 40.2 & 41.6 & 1.03 \\
\hline C & 70 & 100 & 41.1 & 41.6 & 1.01 \\
\hline C & 80 & 100 & 39.5 & 41.6 & 1.05 \\
\hline C & 90 & 115 & 39.8 & 41.6 & 1.04 \\
\hline C & 100 & 115 & 40.3 & 41.6 & 1.03 \\
\hline D & 10 & 80 & 27.3 & 27.3 & 1 \\
\hline D & 20 & 80 & 49.3 & 44.5 & 0.90 \\
\hline D & 30 & 80 & 67.5 & 61.7 & 0.91 \\
\hline D & 40 & 80 & 78.9 & 78.9 & 1 \\
\hline D & 50 & 80 & 76.9 & 78.9 & 1.02 \\
\hline D & 60 & 80 & 74.9 & 78.9 & 1.05 \\
\hline D & 70 & 100 & 75.5 & 78.9 & 1.04 \\
\hline D & 80 & 100 & 76.4 & 78.9 & 1.03 \\
\hline D & 90 & 115 & 74.8 & 78.9 & 1.05 \\
\hline D & 100 & 115 & 76.1 & 78.9 & 1.03 \\
\hline
\end{tabular}


Al-Mosave et al. [67] have also reported the effects of CFRP properties and sections on the steel/CFRP laminate bonds under quasi-static loading. In their research Araldite 420 adhesive was used to join the CFRP sheets together and also to the steel plates. Table 6 presents the mechanical properties of the tested joints from [67].

Table 7 summarizes the values of the failure load, obtained experimentally from the tensile quasi-static tests on the DSJ specimens and numerically by means of the 3D finite element analysis based on the NLS method, including the discrepancies. The choice of 3-D modelling was necessary to enable good comparisons between the actual failure loads and finite element analysis prediction in the cohesive zone model and NLS model.

Figure 12 summarizes the critical longitudinal stress as a function of bonding length for the joints in series $\mathrm{E}, \mathrm{F}, \mathrm{G}$ and $\mathrm{H}$ from [67]. According to the plateaus in Fig. 12, the effective bonding length of the joints in series $E, F, G$ and $H$ are $80,70,90$ and $70 \mathrm{~mm}$, respectively. Using these effective bonding lengths and considering one of the joints as the reference joint, the failure loads of the remaining joints were estimated using the NLS method. A comparison between the NLS predictions and the experimental results is illustrated in Fig. 13. A very good correlation is seen between the experimental data and the NLS estimates for the failure loads in the tested DSJs.

Table 6

Mechanical properties of materials used for joints series E, F, G and H. Al-Mosawe et al. [67].

\begin{tabular}{|lllll|}
\hline Material property & Series $\mathbf{E}$ & Series F & Series $\mathbf{G}$ & Series H \\
\hline Steel length $(\mathrm{mm})$ & 200 & 200 & 200 & 200 \\
\hline Steel cross-section $(\mathrm{mm})$ & $40 * 10$ & $40 * 10$ & $40 * 10$ & $40 * 10$ \\
\hline Steel modulus $(\mathrm{GPa})$ & 203 & 203 & 203 & 203 \\
\hline Steel poisson's ratio & 0.25 & 0.25 & 0.25 & 0.25 \\
\hline CFRP cross-section $(\mathrm{mm})$ & $20 * 1.4$ & $10 * 1.4$ & $20 * 1.4$ & $20 * 1.2$ \\
\hline CFRP type & Low- & Low- & $\begin{array}{l}\text { Normal- } \\
\text { modulus }\end{array}$ & $\begin{array}{l}\text { Ultra-high } \\
\text { modulus }\end{array}$ \\
\hline CFRP modulus (GPa) & 159.4 & 159.4 & 203.0 & 450.0 \\
\hline CFRP poisson's ratio & 0.28 & 0.28 & 0.28 & 0.28 \\
\hline Adhesive modulus $(\mathrm{GPa})$ & 1.9 & 1.9 & 1.9 & 1.9 \\
\hline $\begin{array}{l}\text { Adhesive cross-section } \\
\text { (mm) }\end{array}$ & $20 * 1.4$ & $10 * 1.4$ & $20 * 1.4$ & $20 * 1.2$ \\
\hline Adhesive poisson's ratio & 0.21 & 0.21 & 0.21 & 0.21 \\
\hline Bond length range (mm) & $30-130$ & $30-130$ & $30-130$ & $30-130$ \\
\hline
\end{tabular}


Table 7

Details of experimental results, theoretical failure load predictions from NLS and CZM and PS models along with their corresponding error percentage for the joints series $\mathrm{E}$ through $\mathrm{H}$.

\begin{tabular}{|c|c|c|c|c|c|c|c|}
\hline Series & $\begin{array}{l}\text { Bonding } \\
\text { length, } \\
\text { L1 }\end{array}$ & $\begin{array}{l}\text { Bonding } \\
\text { length, } \\
\text { L2 }\end{array}$ & $\begin{array}{l}\text { Experimental } \\
\text { failure load, } \\
\mathrm{P}_{\text {Exp. }}(\mathrm{kN})\end{array}$ & $\begin{array}{l}\text { Theoretical } \\
\text { failure load: } \\
\text { NLS model } \\
\text { (kN) }\end{array}$ & $\begin{array}{l}\text { Theoretical } \\
\text { failure load: } \\
\text { CZM model } \\
(\mathrm{kN})\end{array}$ & $\begin{array}{l}\text { \%Error: } \\
\text { NLS }\end{array}$ & $\begin{array}{l}\text { \%Error: } \\
\text { CZM }\end{array}$ \\
\hline$E$ & 30 & 100 & 41.0 & 41 & 30.1 & 0 & 26.58 \\
\hline$E$ & 40 & 100 & 50.7 & 50.16 & 40.1 & 1.06 & 20.90 \\
\hline$E$ & 50 & 100 & 60.0 & 59.2 & 51.2 & 1.33 & 14.66 \\
\hline$E$ & 60 & 100 & 69.1 & 68.48 & 59.2 & 0.89 & 14.32 \\
\hline $\mathrm{E}$ & 70 & 110 & 76.5 & 77.64 & 68.4 & 1.49 & 10.58 \\
\hline $\mathrm{E}$ & 80 & 120 & 86.8 & 86.8 & 79.2 & 0 & 8.75 \\
\hline $\mathrm{E}$ & 90 & 130 & 93.6 & 86.8 & 88.1 & 7.26 & 5.87 \\
\hline$E$ & 100 & 140 & 100.3 & 86.8 & 94 & 13.45 & 6.28 \\
\hline E & 110 & 150 & 108.0 & 86.8 & 100.4 & 19.62 & 7.03 \\
\hline E & 120 & 160 & 108.7 & 86.8 & 100.8 & 20.14 & 7.26 \\
\hline$E$ & 130 & 170 & 109.1 & 86.8 & 101 & 20.43 & 7.42 \\
\hline Averag & & & & & & 7.78 & 11.78 \\
\hline$F$ & 30 & 100 & 15.52 & 15.52 & 15.4 & 0 & 0.77 \\
\hline$F$ & 40 & 100 & 20.4 & 19.79 & 20.7 & 3.10 & 1.32 \\
\hline$F$ & 50 & 100 & 25.70 & 24.07 & 26.3 & 6.34 & 2.33 \\
\hline $\mathrm{F}$ & 60 & 100 & 27.63 & 28.34 & 32.1 & 2.56 & 16.17 \\
\hline $\mathrm{F}$ & 70 & 110 & 32.62 & 32.62 & 34 & 0 & 4.23 \\
\hline $\mathrm{F}$ & 80 & 120 & 30.43 & 32.6 & 39.1 & 7.13 & 28.49 \\
\hline $\mathrm{F}$ & 90 & 130 & 31.10 & 32.6 & 42.4 & 4.82 & 36.33 \\
\hline $\mathrm{F}$ & 100 & 140 & 33.48 & 32.6 & 42.8 & 2.62 & 27.83 \\
\hline $\mathrm{F}$ & 110 & 150 & 34.95 & 32.6 & 51.2 & 6.72 & 46.49 \\
\hline $\mathrm{F}$ & 120 & 160 & 31.97 & 32.6 & 51.6 & 1.97 & 61.40 \\
\hline $\mathrm{F}$ & 130 & 170 & 35.03 & 32.6 & 51.7 & 6.93 & 47.58 \\
\hline \multicolumn{5}{|c|}{ Average: } & & 3.84 & 24.81 \\
\hline \multicolumn{5}{|c|}{ Loading [MathJax]/jax/output/CommonHTML/fonts/TeX/fontdata.js } & 30.8 & 0 & 26.49 \\
\hline
\end{tabular}




\begin{tabular}{|c|c|c|c|c|c|c|c|}
\hline Series & $\begin{array}{l}\text { Bonding } \\
\text { length, } \\
\text { L1 }\end{array}$ & $\begin{array}{l}\text { Bonding } \\
\text { length, } \\
\text { L2 }\end{array}$ & $\begin{array}{l}\text { Experimental } \\
\text { failure load, } \\
\mathrm{P}_{\text {Exp. }}(\mathrm{kN})\end{array}$ & $\begin{array}{l}\text { Theoretical } \\
\text { failure load: } \\
\text { NLS model } \\
(\mathrm{kN})\end{array}$ & $\begin{array}{l}\text { Theoretical } \\
\text { failure load: } \\
\text { CZM model } \\
(\mathrm{kN})\end{array}$ & $\begin{array}{l}\text { \%Error: } \\
\text { NLS }\end{array}$ & $\begin{array}{l}\text { \%Error: } \\
\text { CZM }\end{array}$ \\
\hline G & 40 & 100 & 51.7 & 50.61 & 40.1 & 02.38 & 22.43 \\
\hline G & 50 & 100 & 60.7 & 59.33 & 50.4 & 2.10 & 16.96 \\
\hline G & 60 & 100 & 69.8 & 68.05 & 59.4 & 2.25 & 14.89 \\
\hline G & 70 & 110 & 75 & 76.76 & 67.2 & 2.50 & 10.4 \\
\hline G & 80 & 120 & 87.4 & 85.48 & 80 & 2.34 & 8.46 \\
\hline G & 90 & 130 & 94.2 & 94.2 & 89.2 & 0 & 5.30 \\
\hline G & 100 & 140 & 101.3 & 94.2 & 96.3 & 7 & 4.93 \\
\hline G & 110 & 150 & 108.3 & 94.2 & 101.6 & 13.01 & 6.18 \\
\hline G & 120 & 160 & 108.5 & 94.2 & 100.8 & 13.17 & 7.09 \\
\hline G & 130 & 170 & 109.2 & 94.2 & 101.2 & 13.71 & 7.32 \\
\hline Average & & & & & & 4.61 & 11.85 \\
\hline $\mathrm{H}$ & 30 & 100 & 31.76 & 31.76 & 30.1 & 0 & 5.22 \\
\hline $\mathrm{H}$ & 40 & 100 & 43.3 & 42.12 & 40.4 & 2.72 & 6.69 \\
\hline $\mathrm{H}$ & 50 & 100 & 54.4 & 52.48 & 53.4 & 3.52 & 1.83 \\
\hline $\mathrm{H}$ & 60 & 100 & 64.1 & 62.84 & 63.7 & 1.96 & 0.62 \\
\hline $\mathrm{H}$ & 70 & 110 & 73.2 & 73.2 & 71.6 & 0 & 2.18 \\
\hline $\mathrm{H}$ & 80 & 120 & 73.2 & 73.2 & 71.9 & 0 & 1.77 \\
\hline $\mathrm{H}$ & 90 & 130 & 73.2 & 73.2 & 71.4 & 0 & 2.45 \\
\hline $\mathrm{H}$ & 100 & 140 & 73.2 & 73.2 & 72.6 & 0 & 0.81 \\
\hline $\mathrm{H}$ & 110 & 150 & 73.2 & 73.2 & 72.4 & 0 & 1.09 \\
\hline $\mathrm{H}$ & 120 & 160 & 73.2 & 73.2 & 72.1 & 0 & 1.50 \\
\hline $\mathrm{H}$ & 130 & 170 & 73.2 & 73.2 & 72.3 & 0 & 1.22 \\
\hline \multicolumn{6}{|c|}{ Average: } & 0.74 & 2.3 \\
\hline
\end{tabular}

\subsection{Limitations And Advantages Of The Nls Method}

According to the experimental results, the load-displacement curves were linear up to the final fracture

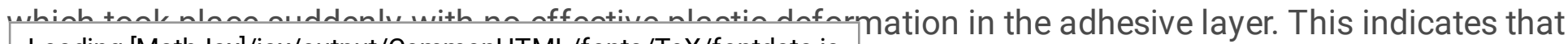
Loading [MathJax]/jax/output/CommonHTML/fonts/TeX/fontdata.js 
the adhesive and the adherents remained in linear elastic state. Therefore, the linear elastic fracture mechanics (LEFM) assumption is reasonable for failure load predictions. There are some limitations and advantages in using the NLS method for DSJs as a failure load prediction model which are briefly discussed in this section. Generally, the term "failure" in this theoretical prediction model for DSJs, describes the state of total failure modes such as adhesive layer failure (cohesive failure), de-bonding between the CFRP and the adhesive layer or between the steel plates and the adhesive layer (adhesive failure), CFRP rupture, CFRP delamination, or a combination of modes.

In order to predict the failure load of the DSJs with different bonding lengths using the NLS model, only two DSJ samples corresponding to the effective bonding length should be tested, which is a major advantage of this methodology. It is very important to note that although the NLS method for DSJs has two experimental parts, the value of the effective bond length can be estimated conveniently and rapidly by applying the NLS method proposed in this research before conducting any experiments. However, in some experimental research (see for instance Refs. [74]) complicated numerical finite element analysis by considering the material nonlinear behavior should be conducted to find the effective bond length. In fact, the simple calculation in predicting the effective bond length using a nonlinear Lagrange approach is the substantial advantage in the NLS method for DSJs.

Various approaches to predict the failure behavior of adhesively bonded joints based on strain, stress, and energy have been suggested in the literature. Almost all of these methods require consideration of the nonlinear behavior of materials in the finite element simulation and need additional material properties to estimate the failure loads of the adhesive joints. However, in the NLS method, failure can be predicted by conducting 2D-linear and 3D-linear elastic analysis. Comparing the current prediction results with previously published results available in the literature reveals that the average accuracy of the nonlinear Lagrange stress is in the same order or even better of the other failure models such as the cohesive zone model and the Hart-Smith model. Due to the advantages noted above, one may recommend the use of the NLS method for predicting the failure load in steel/CFRP DSJs.

\subsection{Conclusions}

The use of CFRP as externally bonded sheets is an effective approach to repair and improve the strength of damaged steel structures. In this paper, a new method, namely the non-linear Lagrange stress method, was presented for failure load prediction in steel/CFRP adhesively bonded DSJs based on longitudinal stress along the adhesive mid-plane. According to this method, after calculating the effective bonding length, the failure of DSJs with different bonding lengths can be predicted. Two sets of experimental tests were conducted on DSJs and the results of theoretical predictions of the NLS model were compared with the experimental results. The accuracy of the NLS method, including 2D and 3D simulations, was also verified by using six set of DSJ test results from the literature. It was revealed that the average accuracy of the NLS method was superior to the CZM method and this approach could estimate the experimental failure loads very well. The results showed that under the best conditions, the NLS model is 
3times more accurate than the CZM model. The main reason for the increased accuracy was attributed to the underlying nonlinear nature of the NLS model.

\section{Declarations}

Authors' contributions $\mathrm{H}$. Hamedi carried out the numerical analysisand respective data analysis, performed the validation study and sketched the paper. A. Kamyabi-Gol built and revised the paper until final form.

Funding This work received no funding.

Data availability The raw/processed data required to reproduce these findings cannot be shared at this time due to technical or time limitations.

\section{Compliance with ethical standards}

Conflict of interest The authors declare that they have no conflict of interest.

Code availability Not applicable.

\section{Compliance with Ethical Standards}

- Disclosure of potential conflicts of interest Not applicable

- Research involving Human Participants and/or Animal Not applicable

- Informed consent Not applicable

\section{References}

[1] J. David Jimenez-Vicaria, Daniel Castro-Fresno, M. Dolores, G. Pulido, Fatigue behaviour of adhesive bonds in tensile CFRP-metal double-strap joints with puddle iron plates taken from a 19th century bridge, Composite Structures, Volume 251, 1 November 2020, 112600.

[2] Wang, S., Liang, W., Duan, L. et al. Effects of loading rates on mechanical property and failure behavior of single-lap adhesive joints with carbon fiber reinforced plastics and aluminum alloys. Int J Adv Manuf Technol 106, 2569-2581 (2020). https://doi.org/10.1007/s00170-019-04804-w

[3] S.C. Jones, S.A. Civjan, Application of fiber reinforced polymer overlays to extend steel fatigue life, J. Composites for Construction. 331 (2003) 4-8.

[4] M. Tavakkolizadeh, H. Saadatmanesh, Strengthening of steel-concrete composite girders using carbon fiber reinforced polymers sheets, J. Structural Engineering. 129 (2003) 30-40.

[5] Manuel A.G. Silva, Hugo Biscaia, Pedro Ribeiro, On factors affecting CFRP-steel bonded joints, 
[6] J. Yao, J.G. Teng, Plate end debonding in FRP-plated RC beams-l: experiments, J. Engineering Structures. 29 (2007) 57-71.

[7] H. Toutanji, L. Zhao, Y. Zhang, Flexural behavior of reinforced concrete beams externally strengthened with CFRP sheets bonded with an inorganic matrix, J. Engineering Structures 28 (2006) 57-66.

[8] Y.W. Kwon, Strength of composite scarf joints. In: Advances in composite materials - eco design and analysis. In Tech Open Access Publisher, Inc., 2011, pp. 467-91.

[9] Ahmad, F.; Hong, J.W.; Choi, H.S.; Park, M.K. Hygro effects on the low-velocity impact behavior of unidirectional CFRP composite plates for aircraft applications. Compos. Struct. 2016, 135, 276-285

[10] A. Pramanik, A.K. Basak, Y. Dong, P.K. Sarker, M.S. Uddin, G. Littlefair, A.R. Dixit, S. Chattopadhyaya, joining of carbon fibre reinforced polymer (CFRP) composites and aluminum alloys - A review, Composites Part A: Applied Science and Manufacturing, Volume 101,2017, Pages 1-29

[11] Jeevi. G, Nayak. Sanjay Kumar, M. Abdul Kader, Review on adhesive joints and their application in hybrid composite structures, Journal of Adhesion Science and Technology, 2019, https://doi.org/10.1080/01694243.2018.1543528

[12] Xi, FF., Yu, L. \& Tu, XW. Framework on robotic percussive riveting for aircraft assembly automation. Adv. Manuf. 1, 112-122 (2013). https://doi.org/10.1007/s40436-013-0014-5

[13] Anna Galinska, Cezary Galinski. Mechanical Joining of Fibre Reinforced Polymer Composites to Metals-A Review. Part II: Riveting, Clinching, Non-Adhesive Form-Locked Joints, Pin and Loop Joining. Polymers 2020, 12, 1681

[14] G. Li, G. Shi, N.C. Bellinger, Assessing the riveting process and the quality of riveted joints in aerospace and other applications, Woodhead Publishing, 2012, Pages 181-214, ISBN 9781845695323, https://doi.org/10.1533/9780857095169.2.179.

[15] Jiang, H., Zeng Technological test, C., Li, G., Cui, J., Effect of locking mode on mechanical properties and failure behavior of CFRP/Al electromagnetic riveted joint, Composite Structures (2020), doi: https://doi.org/10.1016/j.compstruct.2020.113162

[16] Yiwei Chen., Xujing Yang., Maojun Li., Kai Wei, Shuo Li., Mechanical behavior and progressive failure analysis of riveted, bonded and hybrid joints with CFRP-aluminum dissimilar materials, Thin-Walled Structures 139 (2019) 271-280

[17] M.A.Saeimi Sadigha, B.Paygozar, L.F.M.da Silva, E.Martínez-Pañeda, Creep behaviour and tensile response of adhesively bonded polyethylene joints: Single-Lap and Double-Strap, International Journal of Adhesion and Adhesives ; Volume 102, October 2020, 102666 
[19] Groth HL.: Stress singularities and fracture at interface corners in bonded joints. Int. J. Adhes. Adhes. 8, 107-113 (1988).

[20] Tong L.: Strength of adhesively bonded single-lap and lap-shear joints. Int. J. Solids Struct. 35, 26012616 (1998)

[21] De Morais AB, Pereira AB, Teixeira JP, Cavaleiro NC.: Strength of epoxy adhesive-bonded stainlesssteel joints. Int. J. Adhes. Adhes. 27, 679-686 (2007)

[22] Karachalios EF, Adams RD, da Silva LFM.: Single lap joints loaded in tension with high strength steel adherends. Int. J. Adhes. Adhes. 43, 81-95 (2013)

[23] Khoramishad H, Razavi SMJ.: Metallic fiber-reinforced adhesively bonded joints. Int. J. Adhes. Adhes. $55,114-122$ (2014)

[24] Ayatollahi MR, Nemati Giv A, Razavi SMJ, Khoramishad H.: Mechanical properties of adhesively single lap bonded joints reinforced with multi-walled carbon nanotubes and silica nanoparticles. J. Adhes. (2016)

[25] Ayatollahi MR, Akhavan-Safar A.: Failure load prediction of single lap adhesive joints based on a new linear elastic criterion. Theor. Appl. Fract. Mech. 80, 210-217 (2015).

[26] Chen Z, Adams RD, Da Silva LFM.: Prediction of crack initiation and propagation of adhesive lap joints using an energy failure criterion. Eng. Fract. Mech. 78, 990-1007 (2011)

[27] Hell S, Weißgraeber P, Felger J, Becker W.: A coupled stress and energy criterion for the assessment of crack initiation in single lap joints: a numerical approach. Eng. Fract. Mech. 117, 112-126 (2014)

[28] Chalkley P, Rose F.: Stress analysis of double-strap bonded joints using a variational method. Int. J. Adhes. Adhes. 21, 241-247 (2001)

[29] Barroso A, Mantic V, París F.: Singularity parameter determination in adhesively bonded lap joints for use in failure criteria. Compos. Sci. Technol. 68, 2671-2677 (2008)

[30] Lee HK, Pyo SH, Kim BR.: On joint strengths, peel stresses and failure modes in adhesively bonded double-strap and supported single-lap GFRP joints. Compos. Struct. 87, 44-54 (2009).

[31] Fawzia S, Zhao XL, Al-Mahaidi R.: Bond-slip models for double strap joints strengthened by CFRP. Compos. Struct. 92, 2137-2145 (2010)

[32] Fawzia S, Al-Mahaidi R, Zhao XL.: Experimental and finite element analysis of a double strap joint between steel plates and normal modulus CFRP. Compos. struct. 75, 156-62 (2006)

[33] Fawzia S, Zhao XL, Al-Mahaidi R, Rizkalla S.: Bond characteristics between CFRP and steel plates in 
[34] Majidi HR, Razavi SMJ, Berto F.: Failure Assessment of Steel/CFRP Double Strap Joints. Metals. 7(7), 255 (2017). (DOI:10.3390/met7070255)

[35] Al-Shawaf A.: Modelling wet lay-up CFRP-steel bond failures at extreme temperatures using stressbased approach. Int. J. Adhes. Adhes. 31, 416-28 (2011)

[36] Nguyen T-C, Bai Y, Zhao XL, Al-Mahaidi R.: Effects of ultraviolet radiation and associated elevated temperature on mechanical performance of steel/CFRP double strap joints. Compos. Struct. 94, 3563$3573(2012)$

[37] Nguyen T-C, Bai Y, Zhao XL, Al-Mahaidi R.: Curing effects on steel/CFRP double strap joints under combined mechanical load, temperature and humidity. Constr. Build. Mater. 40, 899-907 (2013).

[38] Nguyen TC, Bai Y, Zhao XL, Bambach MR, Al-Mahaidi R.: Temperature Effect on Adhesively Bonded CFRP and Steel Double Strap Joints. Advances in FRP Composites in Civil Engineering: Springer. 877-880 (2011)

[39] Nguyen T-C, Bai Y, Zhao XL, Al-Mahaidi R.: Mechanical characterization of steel/CFRP double strap joints at elevated temperatures. Compos. Struct. 93, 1604-1612 (2011)

[40] Zhao XL, Zhang L.: State-of-the-art review on FRP strengthened steel structures. Eng. Struct. 29, 1808$1823(2007)$

[41] Mohee FM, Al-Mayah A, Plumtree A.: Anchors for CFRP plates: State-of-the-art review and future potential. Composites Part B. 90, 432-442 (2016)

[42] Fawzia S, Zhao XL, Al-Mahaidi R, Rizkalla S.: Bond characteristics between CFRP and steel plates in double strap joints. Int. Adv. Steel. Const. 1, 17-27 (2005)

[43] Miller TC, Chajes MJ, Mertz DR.: Hastings JN. Strengthening of a steel bridge girder using CFRP plates. J. Bridge Eng. 6, 514-522 (2001)

[44] Bocciarelli M, Colombi P, Fava G, Poggi C.: Prediction of debonding strength of tensile steel/CFRP joints using fracture mechanics and stress based criteria. Eng. Fract. Mech. 76, 299- 313 (2009)

[45] Liu H, Xiao Z, Zhao XL, Al-Mahaidi R.: Prediction of fatigue life for CFRP-strengthened steel plates. Thin Walled Struct. 47, 1069-1077 (2009).

[46] Teng JG, Fernando D, Yu T.: Finite element modelling of debonding failures in steel beams flexurally strengthened with CFRP laminates. Eng. Struct. 86, 213-224 (2015).

[47] Kazem H, Guaderrama L, Selim H, Rizkalla S, Kobayashi A.: Strengthening of steel plates subjected to uniaxial compression using small-diameter CFRP strands. Constr. Build. Mater. 111, 223-236 (2016) 
[48] Meng F, Li W, Fan H, Zhou Y.: A nonlinear theory for CFRP strengthened aluminum beam. Compos. Struct. 131, 574-577 (2015)

[49] Kashfuddoja M, Ramji M.: Assessment of local strain field in adhesive layer of an unsymmetrically repaired CFRP panel using digital image correlation. Int. J. Adhes. Adhes. 57, 57-69 (2015)

[50] Kashfuddoja M, Ramji M.: Whole-field strain analysis and damage assessment of adhesively bonded patch repair of CFRP laminates using 3D-DIC and FEA. Composites Part B. 53, 46-61 (2013)

[51] Verbruggen S, Aggelis DG, Tysmans T, Wastiels J.: Bending of beams externally reinforced with TRC and CFRP monitored by DIC and AE. Compos. Struct. 112, 113-121 (2014).

[52] Srilakshmi R, Ramji M, Chinthapenta V.: Fatigue crack growth study of CFRP patch repaired Al 2014T6 panel having an inclined center crack using FEA and DIC. Eng. Fract. Mech. 134, 182- 201 (2015)

[53] Ahmad H, Crocombe AD, Smith PA.: Strength prediction in CFRP woven laminate bolted doublelap joints under quasi-static loading using XFEM. Composites Part A. 56, 192-202 (2014).

[54] Ahmad H, Crocombe AD, Smith PA.: Strength prediction in CFRP woven laminate bolted singlelap joints under quasi-static loading using XFEM. Composites Part A. 66, 82-93 (2014).

[55] Ataş A, Soutis C.: Application of cohesive zone elements in damage analysis of composites: Strength prediction of a single-bolted joint in CFRP laminates. Int. J. Non Linear Mech. 66, 96- 104 (2014).

[56] Ataş A, Soutis C.: Strength prediction of bolted joints in CFRP composite laminates using cohesive zone elements. Composites Part B. 58, 25-34 (2014)

[57] Campilho RDSG, De Moura MFSF, Domingues JJMS.: Using a cohesive damage model to predict the tensile behaviour of CFRP single-strap repairs. Int. J. Solids Struct. 45, 1497-512 (2008)

[58] Al-Zubaidy H, Al-Mahaidi R, Zhao XL.: Finite element modelling of CFRP/steel double strap joints subjected to dynamic tensile loadings. Compos. Struct. 99, 48-61 (2013)

[59] S. Xia, J. Teng, Behaviour of FRP-to-steel bonded joints. In: Proceedings of the international symposium on bond behaviour of FRP in structures (BBFS), Hong Kong, December; 2005, pp. 419-26.

[60] S. Fawzia, R. Al-Mahaidi, XL. Zhao, Experimental and finite element analysis of a double strap joint between steel plates and normal modulus CFRP, J. Compos Struct, 156 (2006) 62-75.

[61] S. Fawzia, XL. Zhao, R. Al-Mahaidi, Bond-slip models for double strap joints strengthened by CFRP, J. Compos Struct, 2137 (2010) 45-92.

[62] C. Wu, XL. Zhao, WH. Duan, R. Al-Mahaidi, Bond characteristics between ultra-high modulus CFRP laminates and steel, J. Thin Wall Struct, 147 (2012) 51-57.

Loading [MathJax]/jax/output/CommonHTML/fonts/TeX/fontdata.js

Page 20/30 
[63] HB. Liu, XL. Zhao, R. Al-Mahaidi, Effect of fatigue loading on bond strength between CFRP sheets and steel plates, J. Struct Stabil Dynam, 1 (2010) 10-20.

[64] T. Bai, XL. Zhao, R. Al-Mahaidi, Post yield behaviour of CFRP steel adhesive joints under static and cyclic loading, In: 5th International conference on the Thin Wallded structures, Brisibane, June; 2008.

[65] QR. Yue, FM. Peng, YX. Yang, N. Zhang, Experimental and finite element studies on deteriorated steel members repaired with CFRP sheets, In: Proceedings of the 2nd international conference on FRP composites in civil engineering (CICE), Adelaide, 8-10 December, 2005, pp. 121-6.

[66] S. Xia, J. Teng, Behaviour of FRP-to-steel bonded joints. In: Proceedings of the international symposium on bond behaviour of FRP in structures (BBFS), Hong Kong, December; 2005, pp. 419-26.

[67] Alaa. Al-Mosawe, Riadh. Al-Mahaidi, Xiao-Ling. Zhao, Effect of CFRP properties, on the bond characteristics between steel and CFRP laminate under quasi-static loading, J. Construction and Building Materials. 98 (2015) 489-501.

[68] Haider. Al-Zubaidy, Riadh. Al-Mahaidi, Xiao-Ling. Zhao, Experimental investigation of bond characteristics between CFRP fabrics and steel plate joints under impact tensile loads, J. Composite Structures. 94 (2012) 10-18.

[69] M.R. Ayatollahi, A. Nemati Giv, S.M.J Razavi, H. Khoramishad, Mechanical properties of adhesively single lap-bonded joints reinforced with multi-walled carbon nanotubes and silica nanoparticles, J. Adhes. (2016) 896-913.

[70] E. A. S. Marques, Lucas F. M. da Silva, Joint Strength Optimization of Adhesively Bonded Patches, Taylor \& Francis, 2008

[71] ASTM E8/E8M-16a. Standard Test Methods for Tension Testing of Metallic Materials; ASTM International: West Conshohocken, PA, USA, 2016; Available online: www.astm.org (access on 6 July 2017).

[72] ASTM. Properties, Standard Test Method for Tensile Properties of Plastics; American Society for Testing and Materials: West Conshohocken, PA, USA, 1996.

[73] ABAQUS, ABAQUS User's Manual Version 6.13, Dassault Systemes Simulia Corp, Providence, RI, USA, 2013.

[74] G. Li, P. Lee-Sullivan, RW. Thring, Nonlinear finite element analysis of stress and strain distributions across the adhesive thickness in composite single-lap joints, J.Compos Struct. 46 (1999) 395-403.

[75] A.M. Rubinov, Lagrange-type Functions in Constrained Non-Convex Optimization. United States, Springer US, 2013. 
Figures

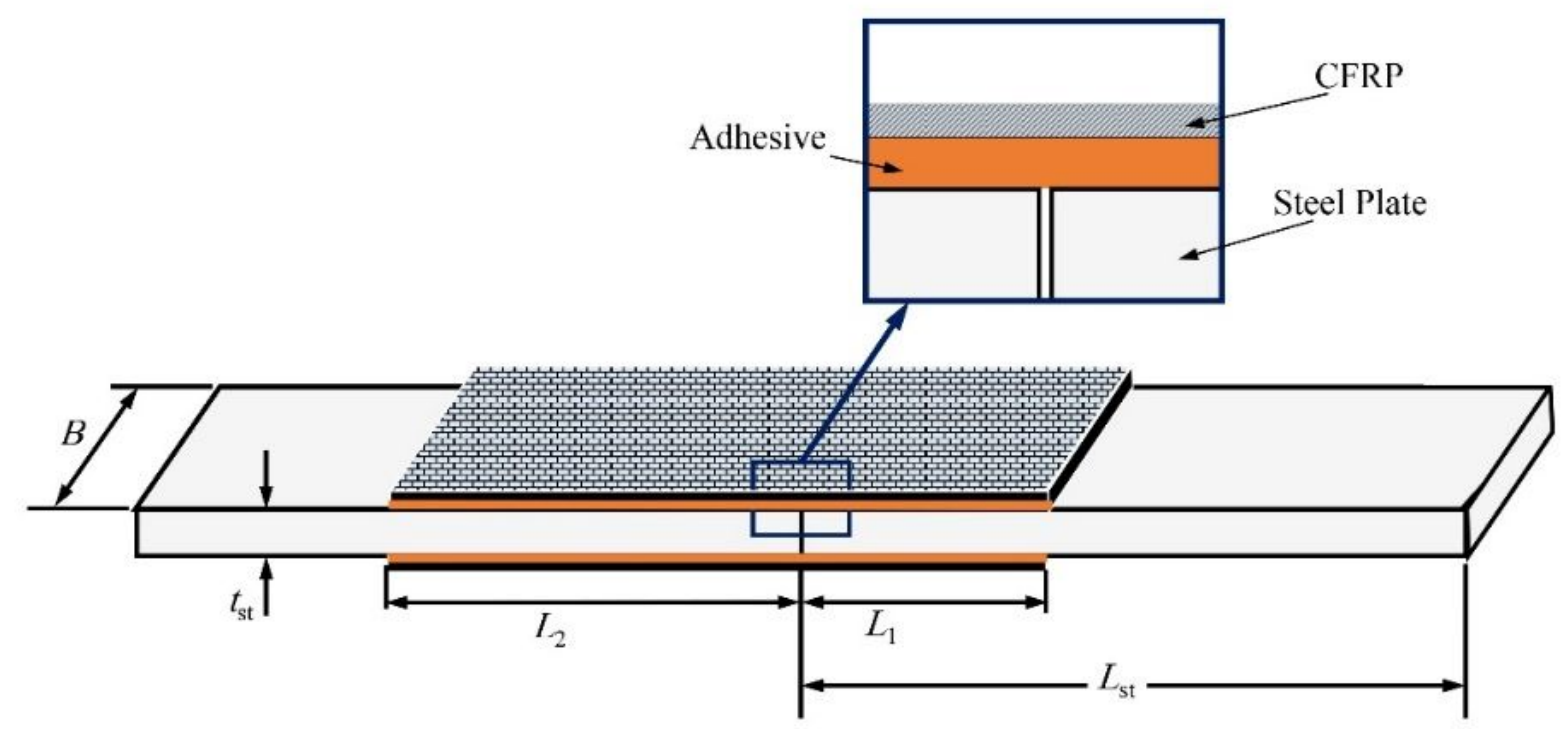

Figure 1

A schematic of steel/CFRP double strap joint. 


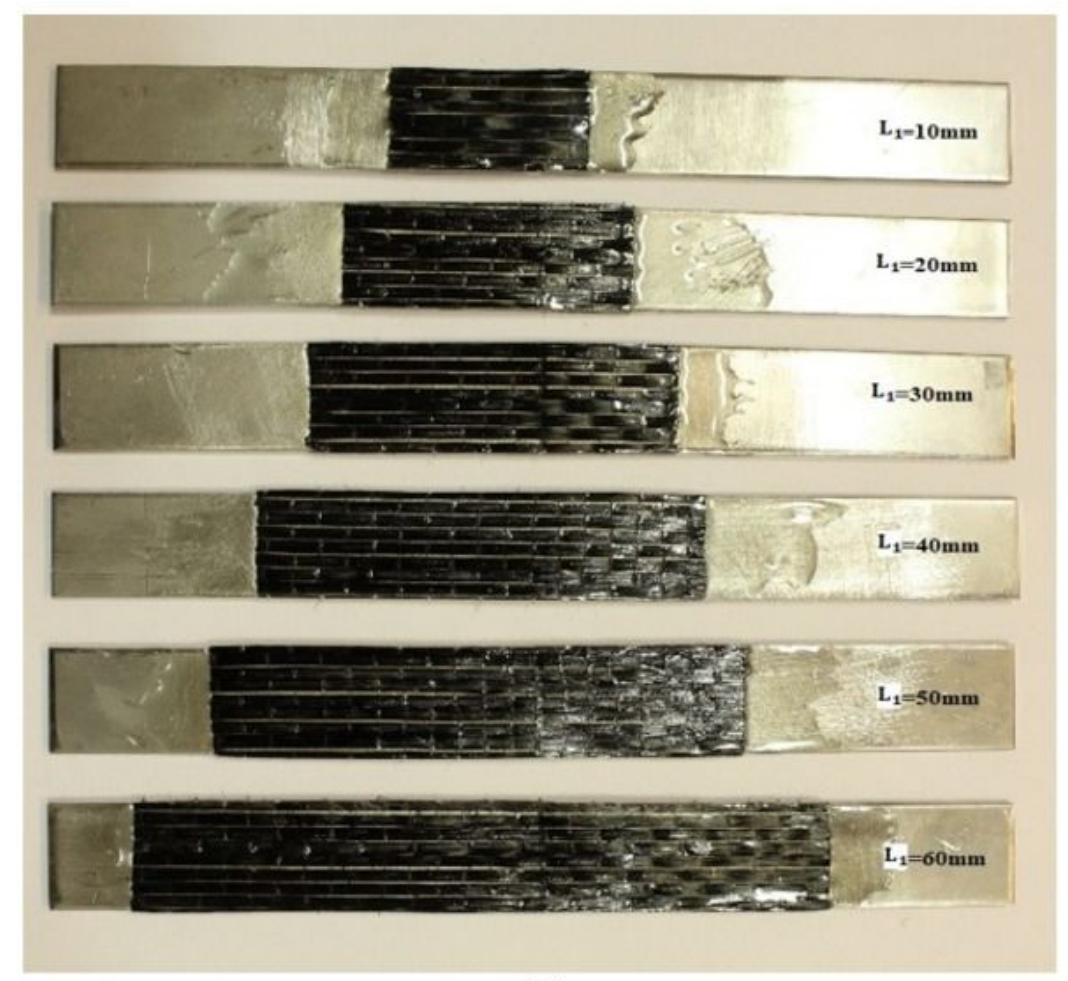

(a)

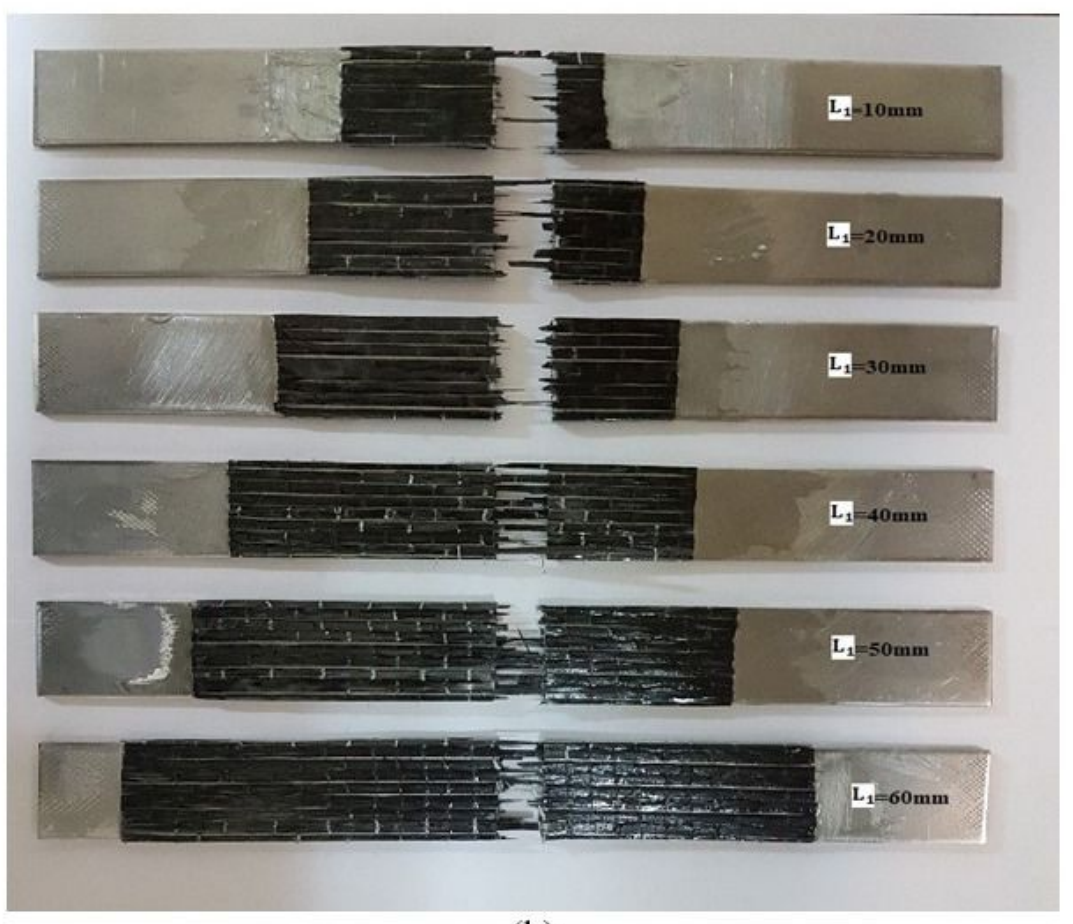

(b)

\section{Figure 2}

Double strap joints (DSJs) prepared for experiments (a) before the test; (b) after the test 


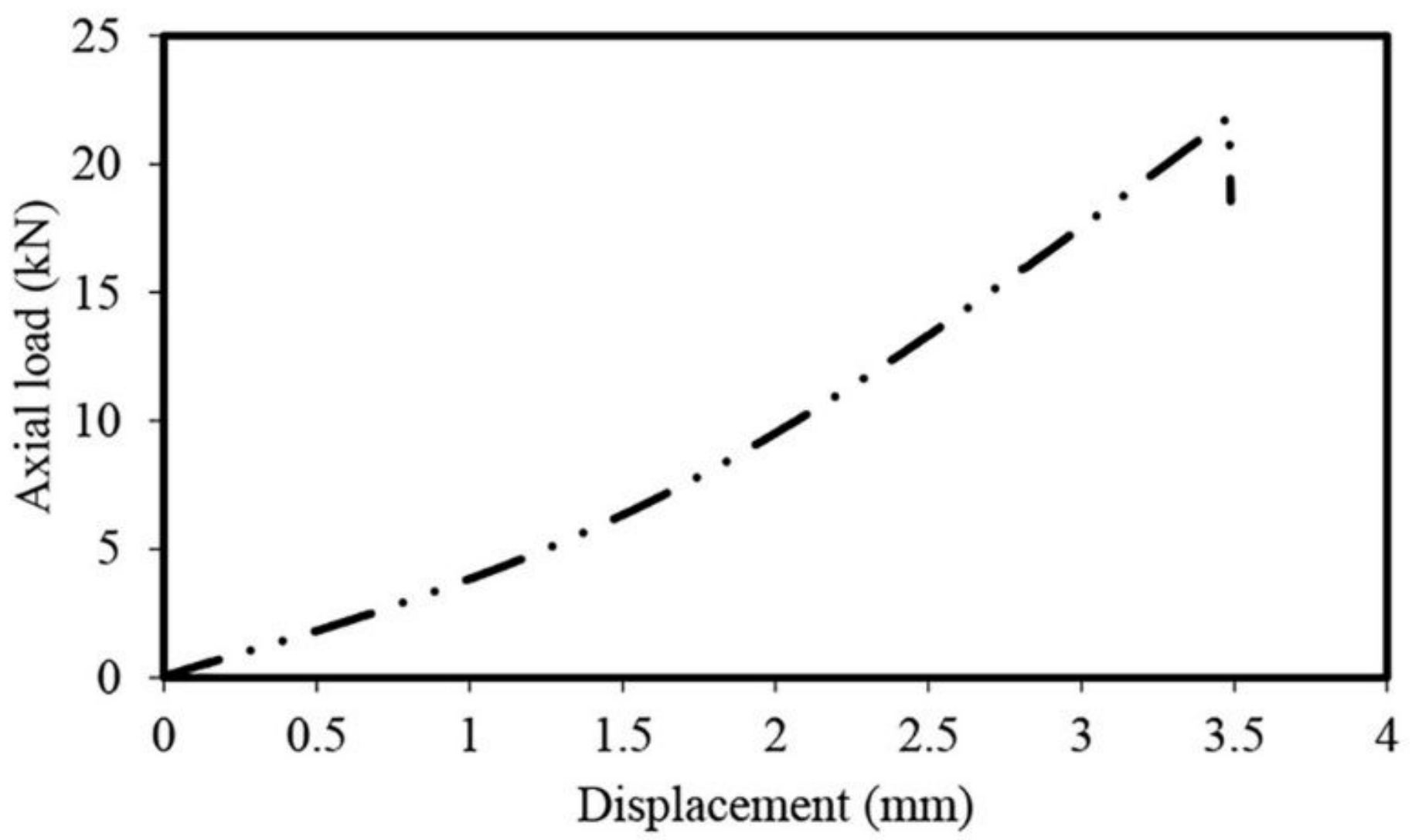

Figure 3

An example of a load-displacement curve for the steel/CFRP DSJs under tensile quasi-static loading Symmetric Boundary Condition

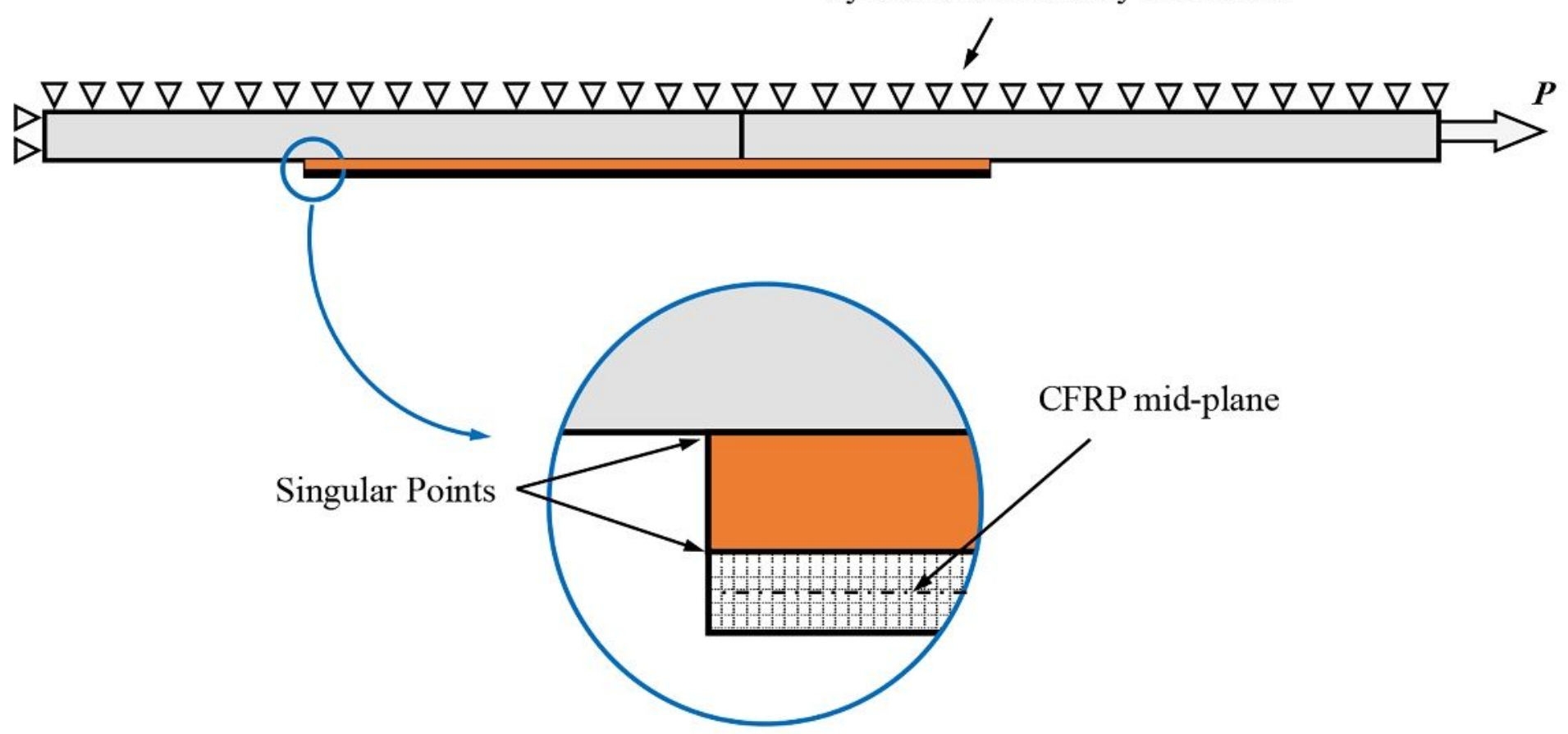


Applied boundary and loading conditions in the finite element model. (P: applied load)

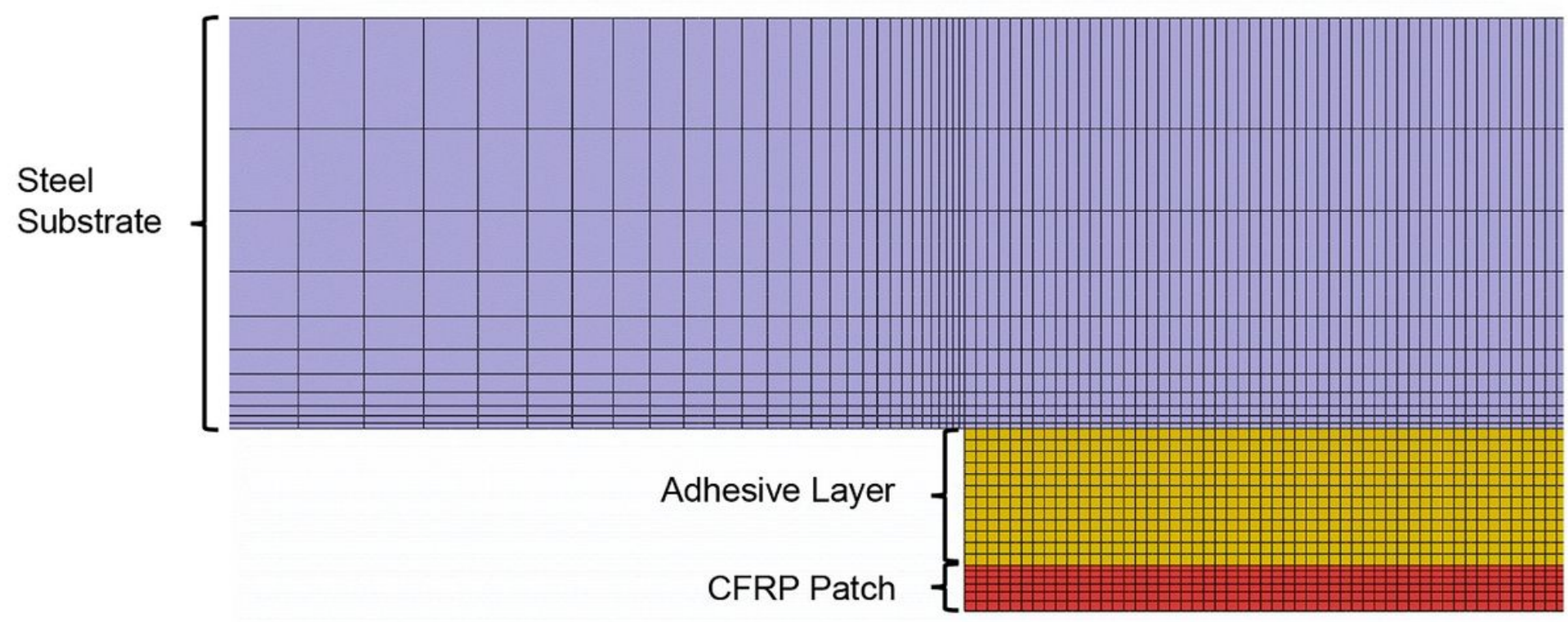

Figure 5

A typical mesh pattern used for DSJ models in this research.

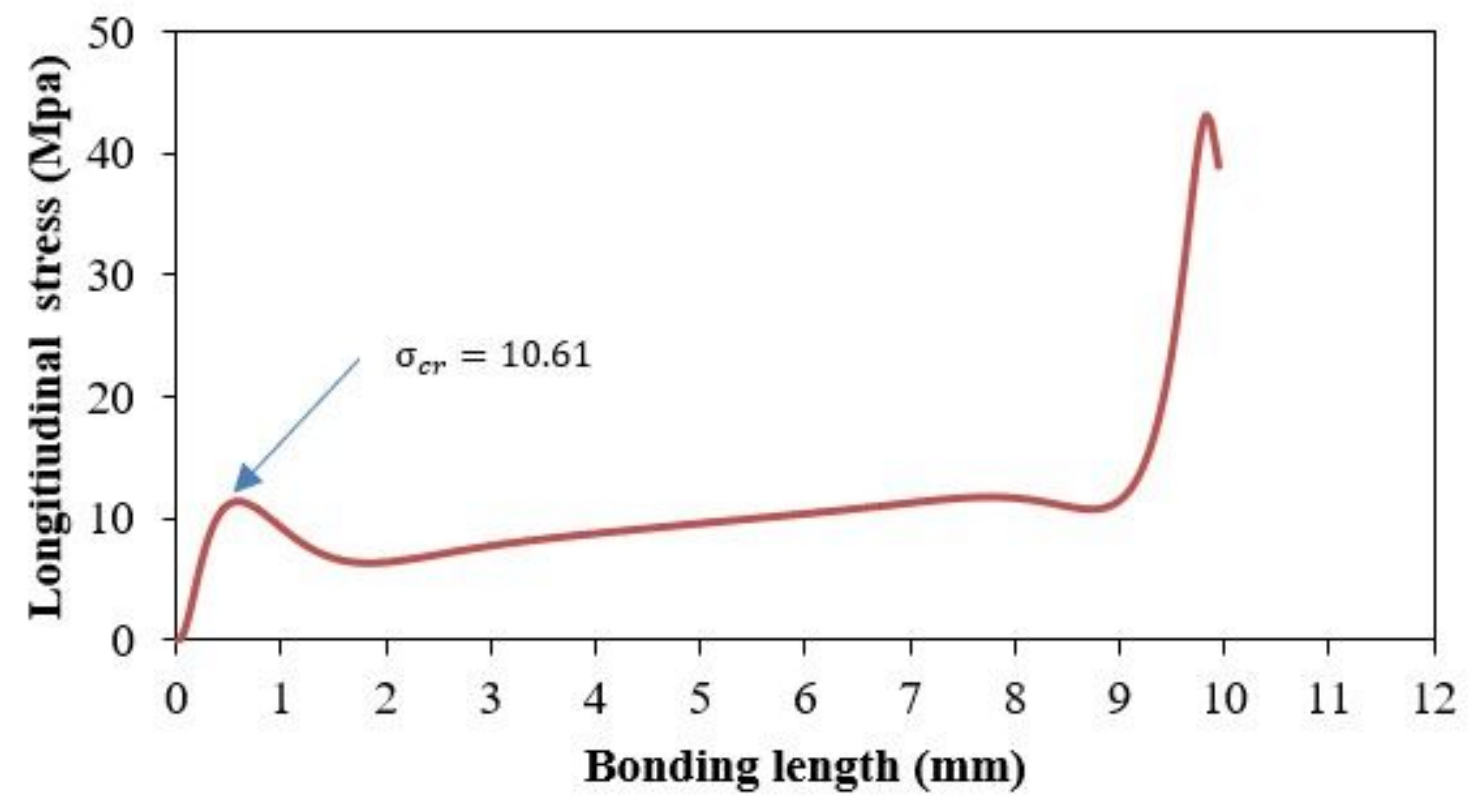

Figure 6

Longitudinal stress distribution along the path defined in the mid-plane of the adhesive layer for the present experimental series $\mathrm{A}-\mathrm{L} 1=10$. 


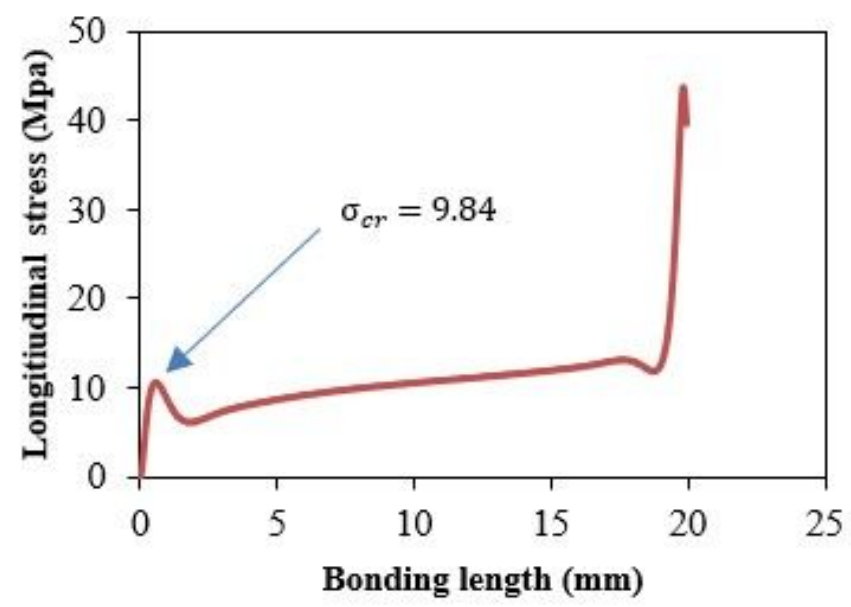

(a)

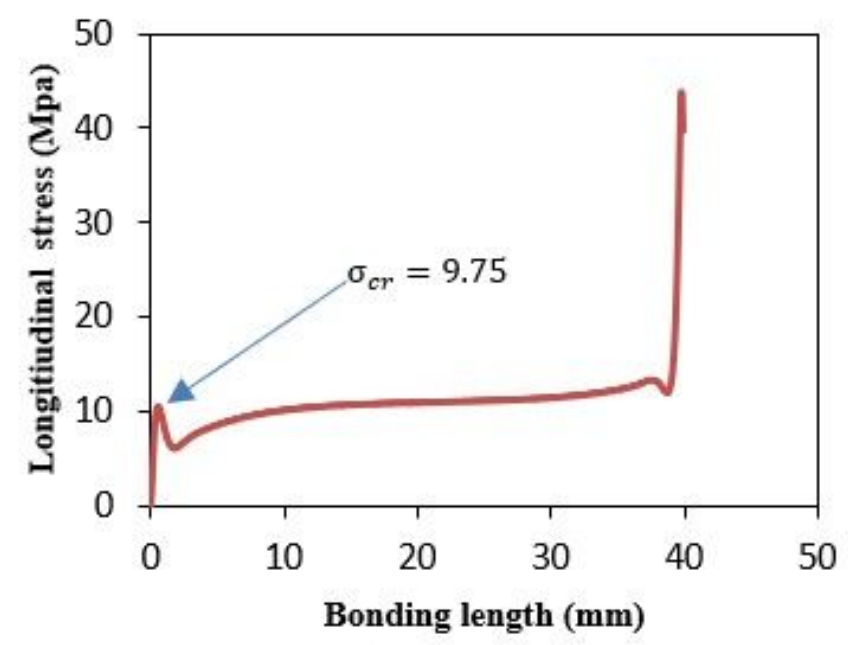

(c)

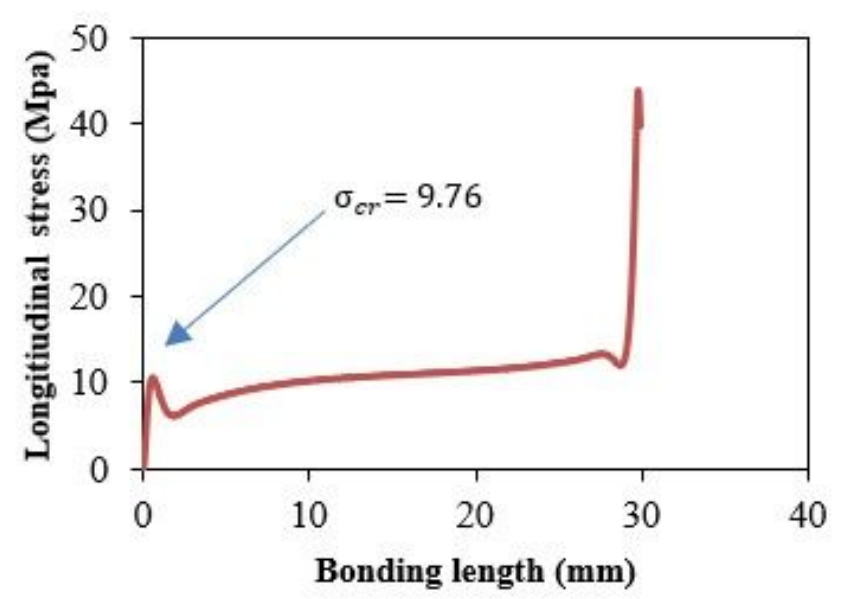

(b)

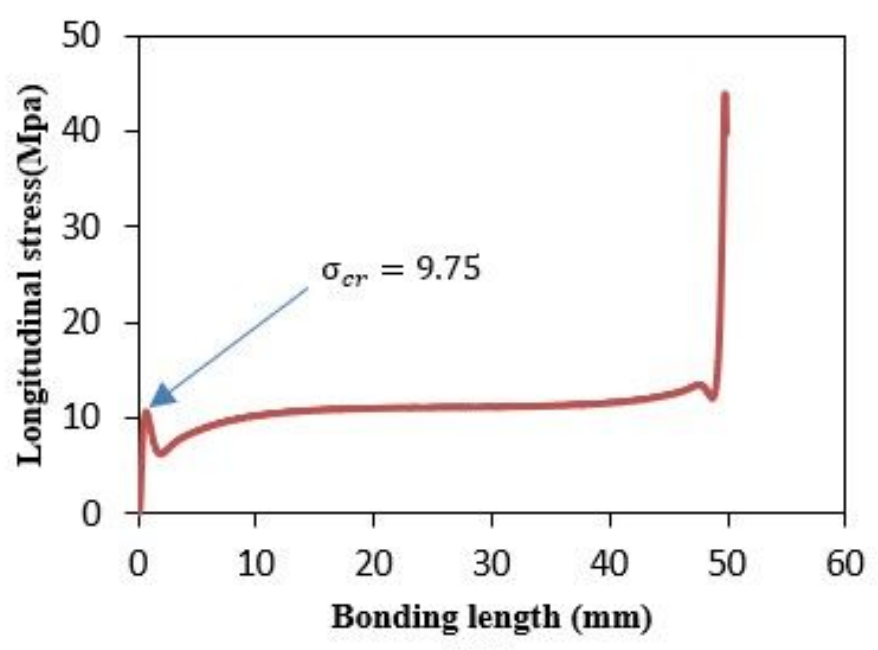

(d)

Figure 7

Longitudinal stress distribution along the path defined in the mid-plane of the adhesive layer for the present experimental series - (a) L1 $=20 \mathrm{~mm}$; (b) L1 = $30 \mathrm{~mm}$; (c) L1 = $40 \mathrm{~mm}$; (d) L1 = $50 \mathrm{~mm}$ (applied stress for all the specimens: $1200 \mathrm{MPa}$ ). 


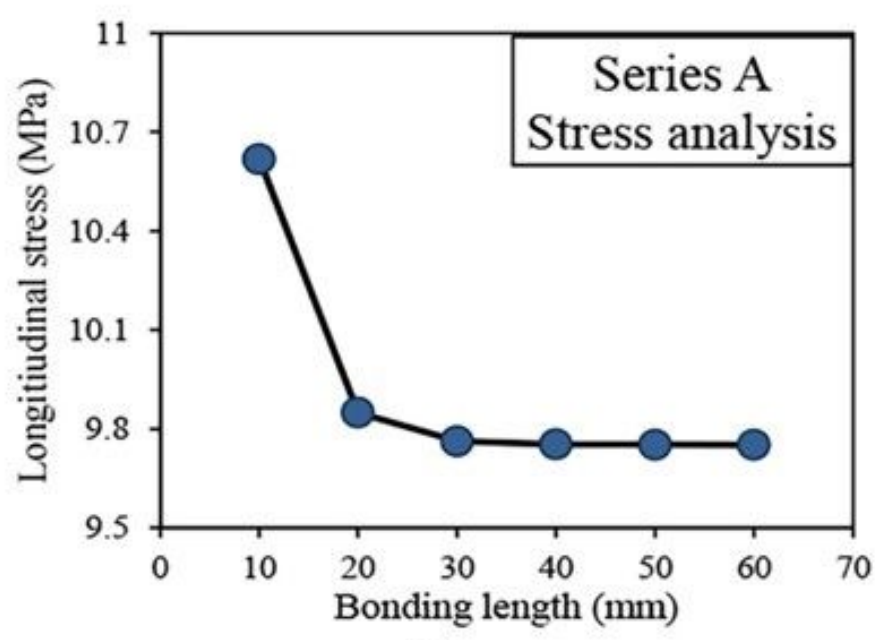

(a)

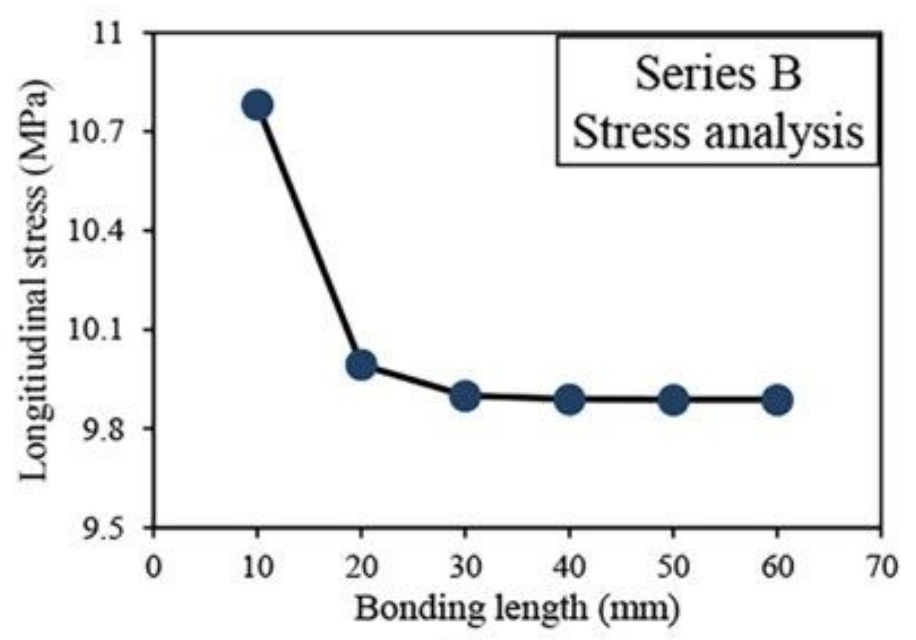

(b)

\section{Figure 8}

The variation of critical longitudinal stress for different bonding lengths (applied stress for all the specimens: $1200 \mathrm{MPa}$ ).

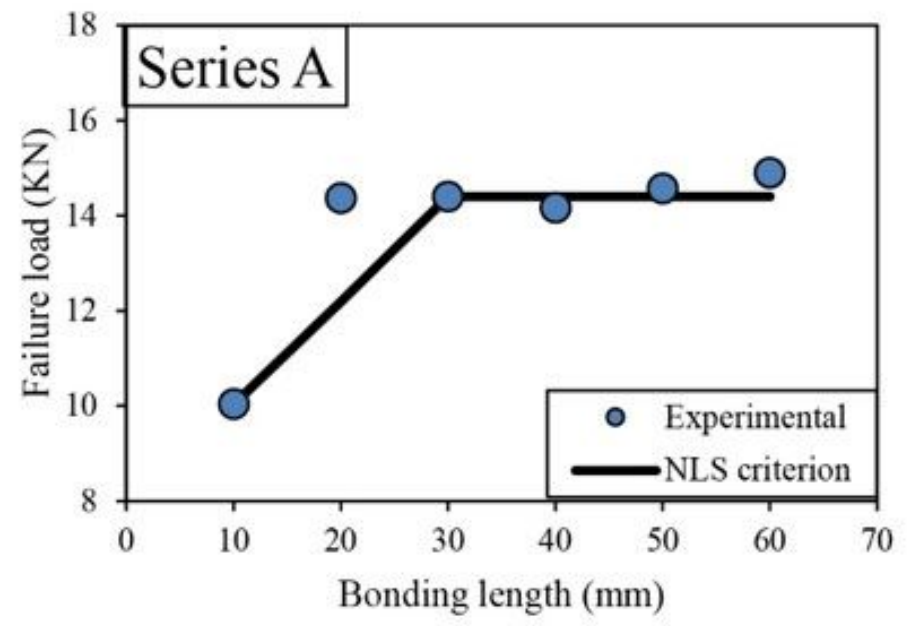

(a)

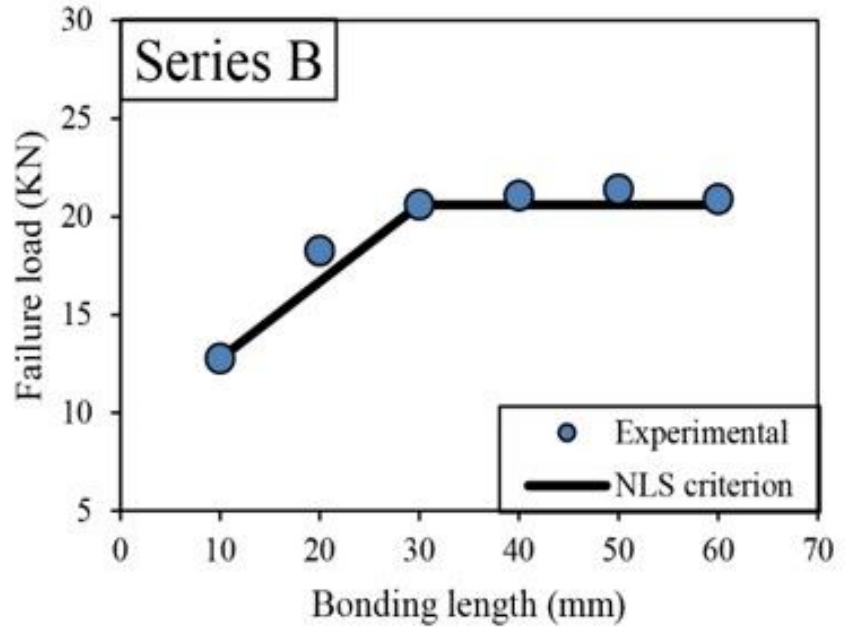

(b)

Figure 9

Comparison between the experimental failure loads of DSJs and the theoretical predictions obtained by means of point stress (NLS) method; (a) series A; (b) series B. 


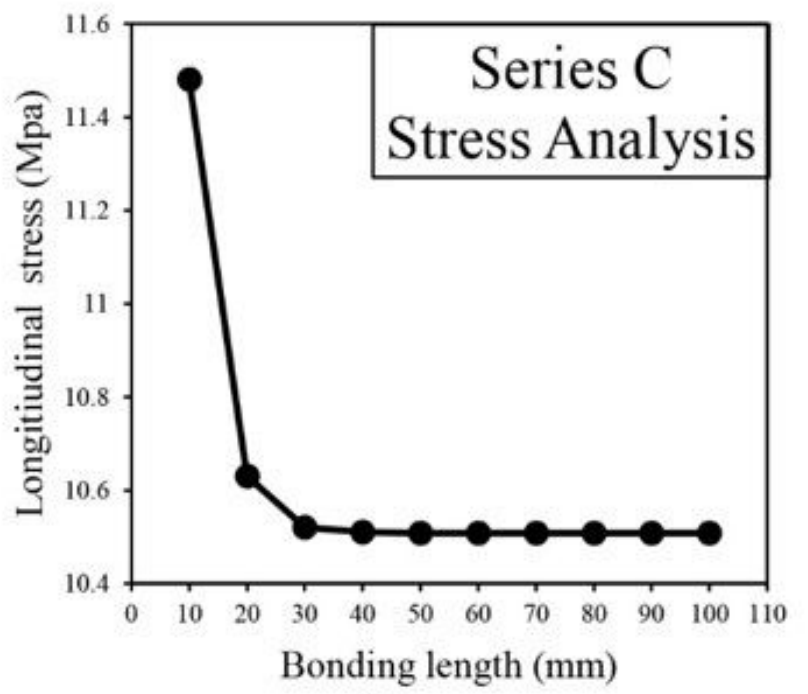

(a)

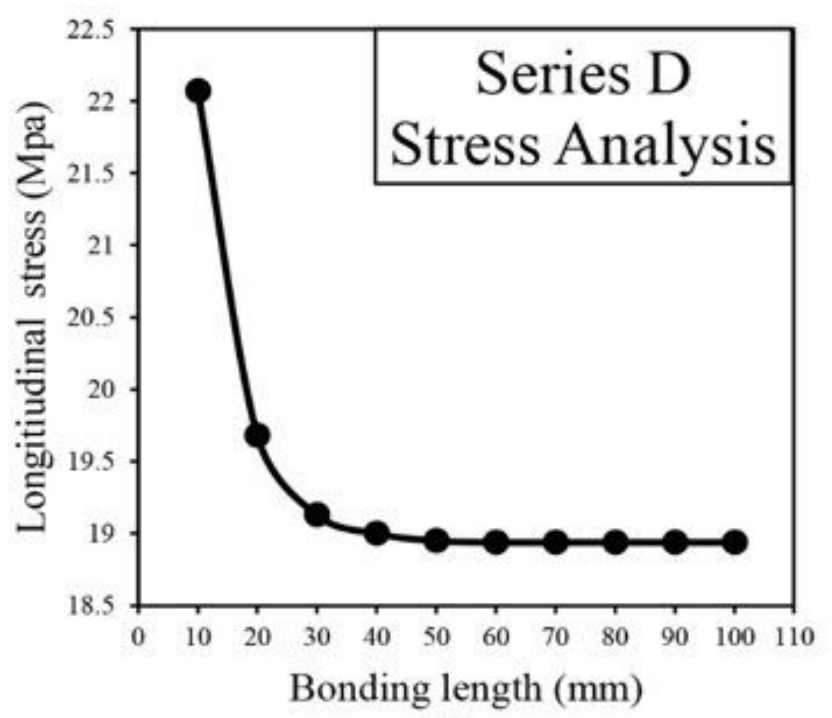

(b)

Figure 10

The variation of critical longitudinal stress for different bonding lengths (applied stress for all the specimens: $1200 \mathrm{MPa}$ ); (a) series C; (b) series D.

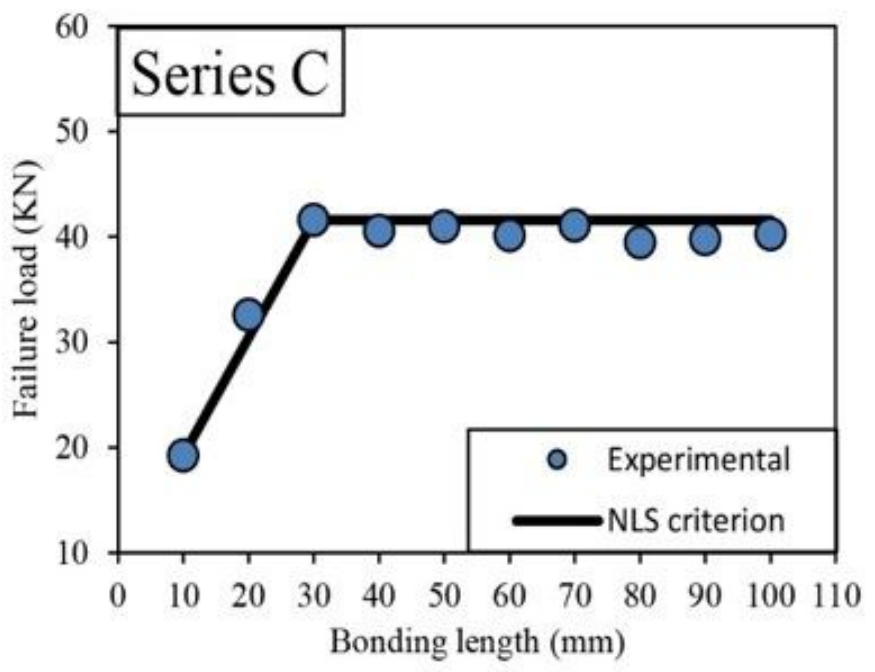

(a)

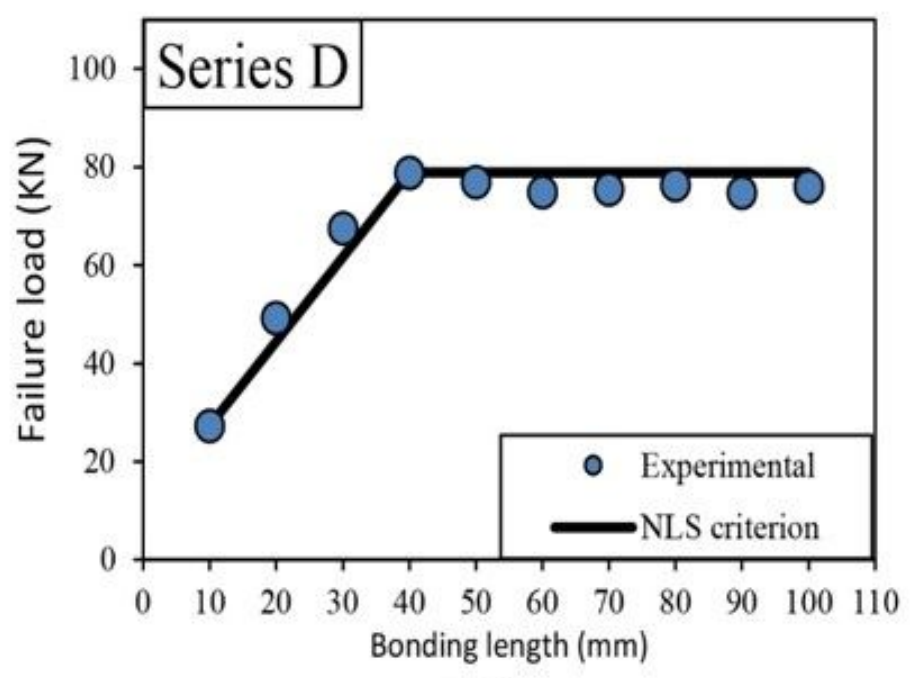

(b)

\section{Figure 11}

Comparison between the experimental failure loads of Double Strap Joints and the theoretical predictions obtained by means of NLS method; (a) series C; (b) series D. 


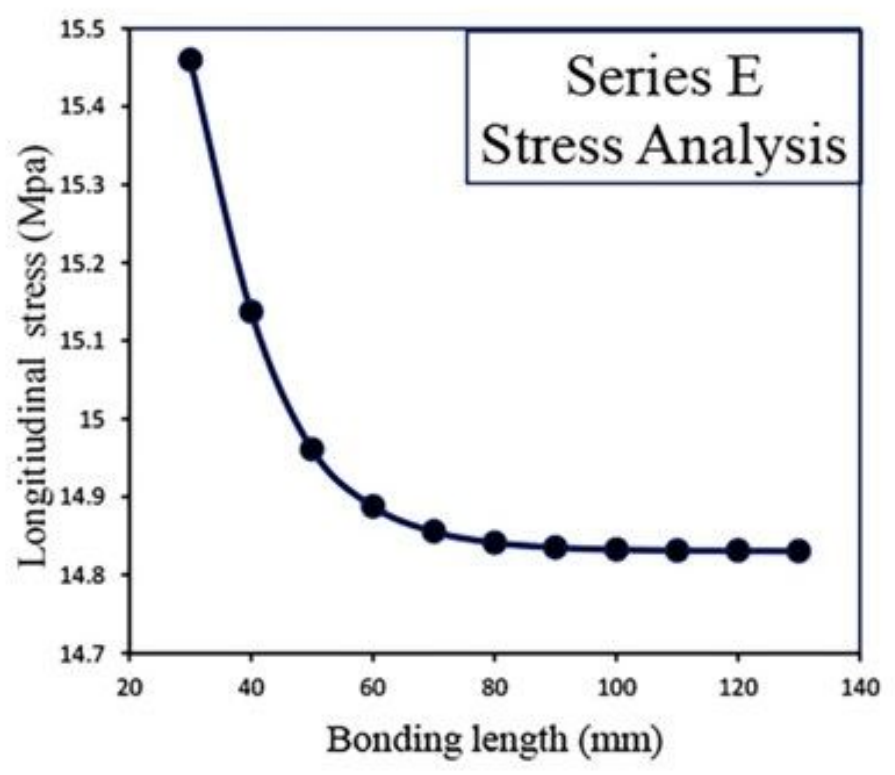

(a)

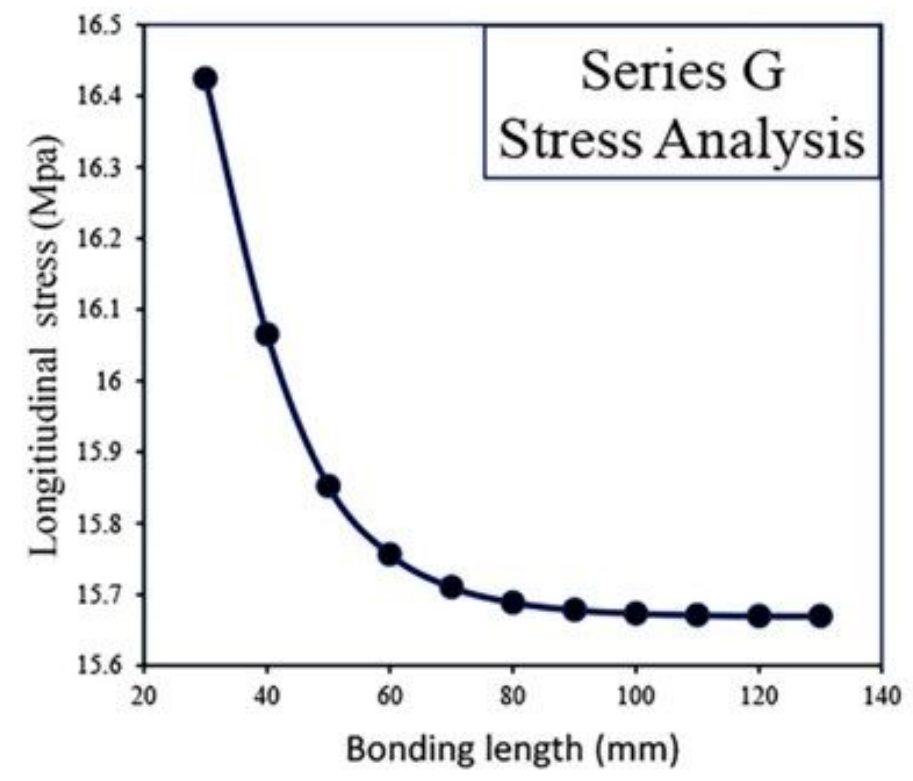

(c)

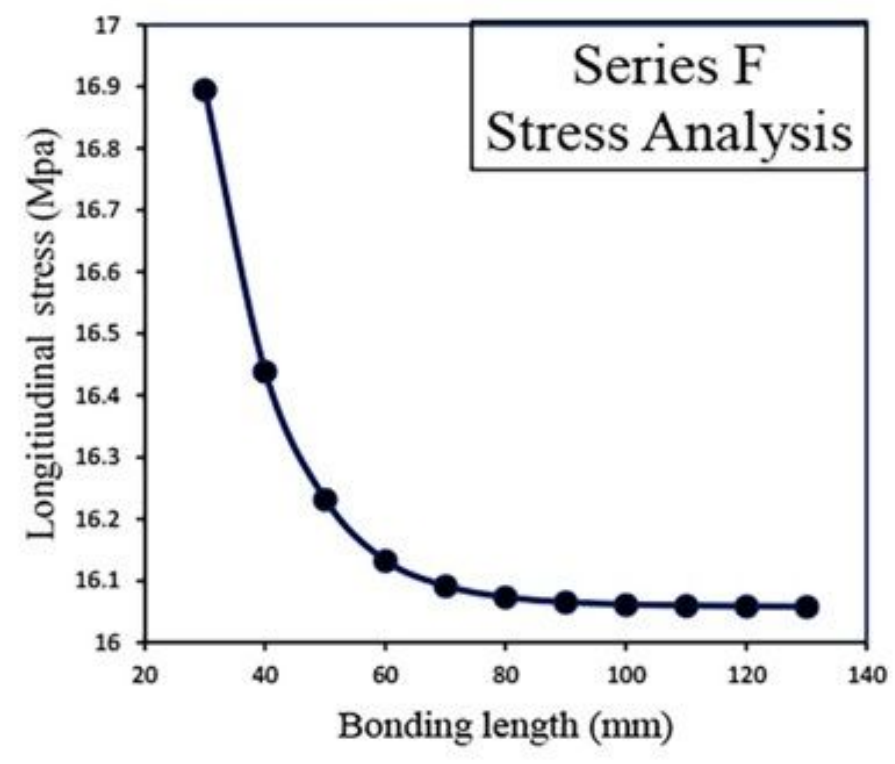

(b)

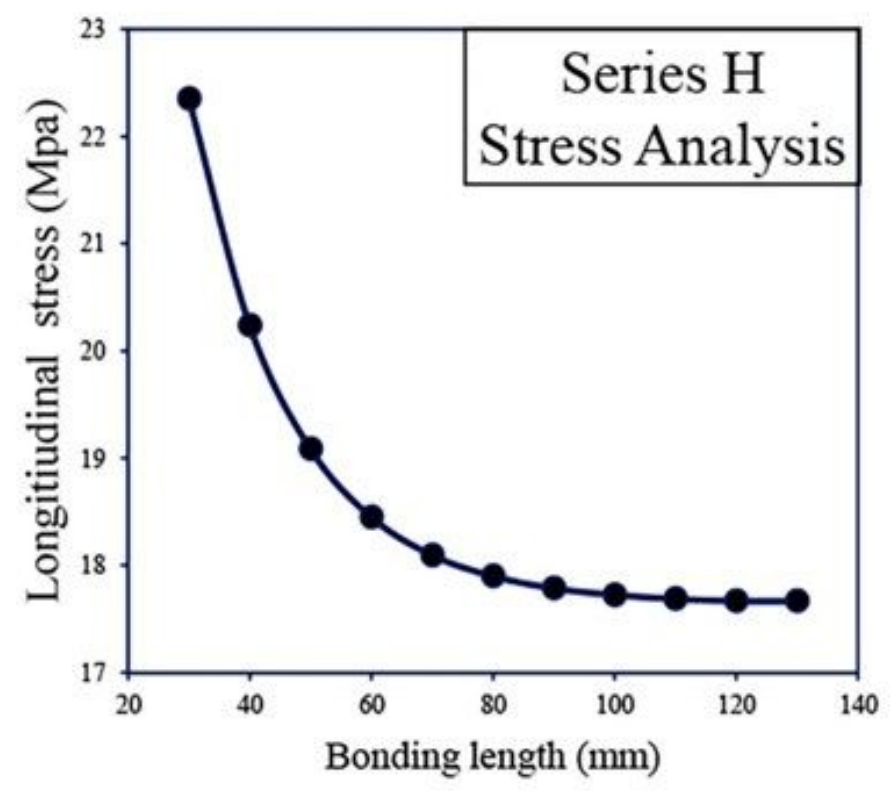

(d)

Figure 12

The variation of critical longitudinal stress for different bonding lengths (applied stress for all the specimens: $1200 \mathrm{MPa}$ ); (a) series $\mathrm{E}$; (b) series F; (c) series G; (d) series $\mathrm{H}$. 


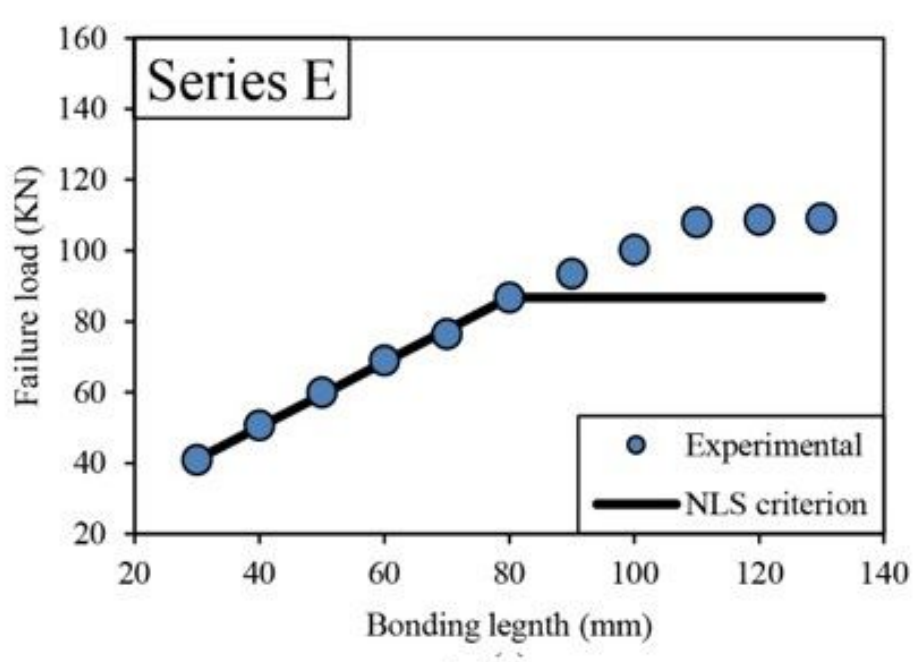

(a)

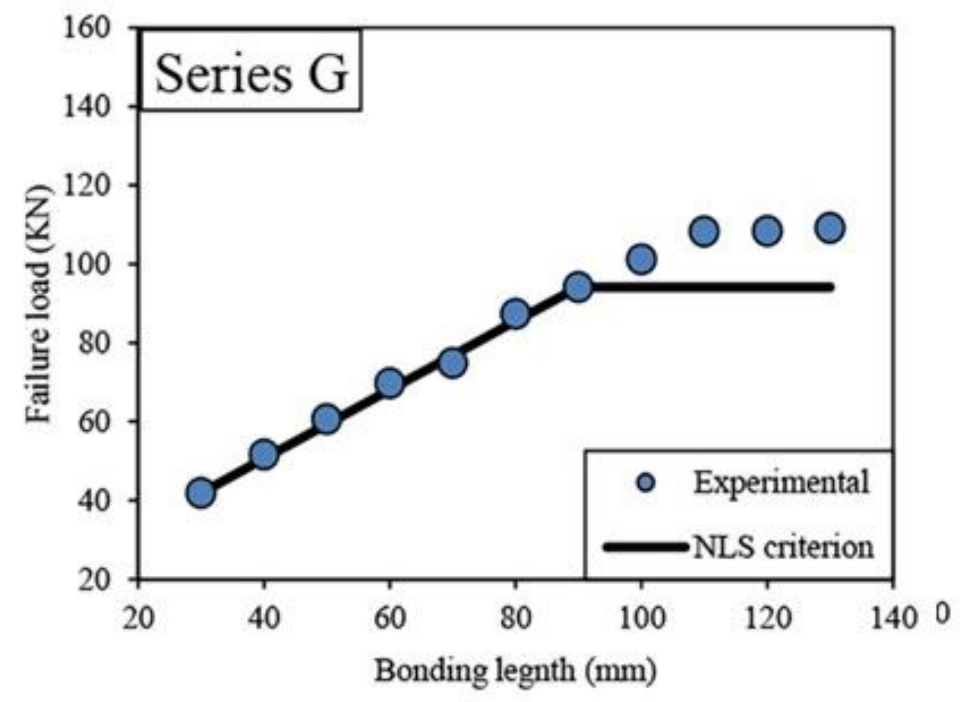

(c)

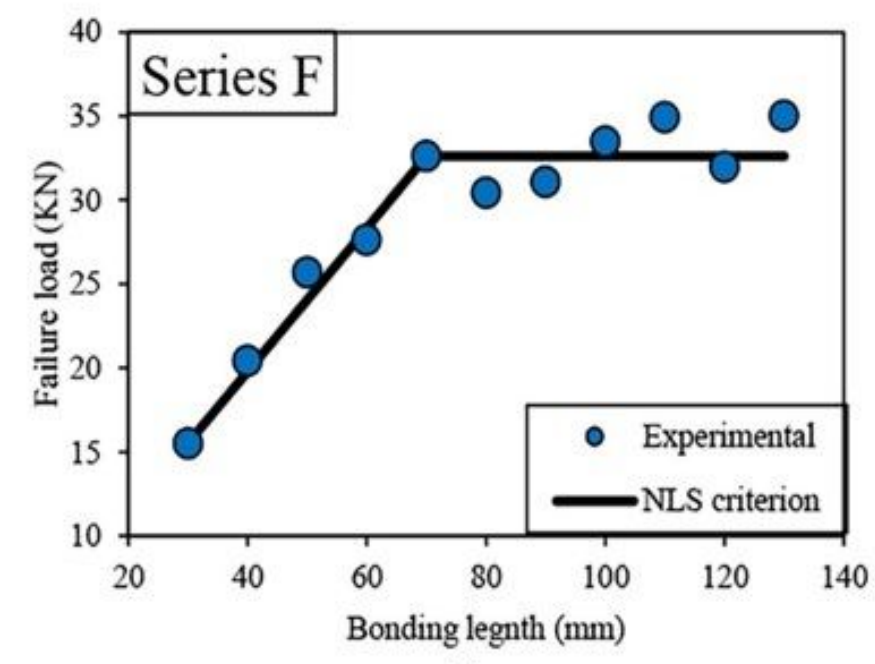

(b)

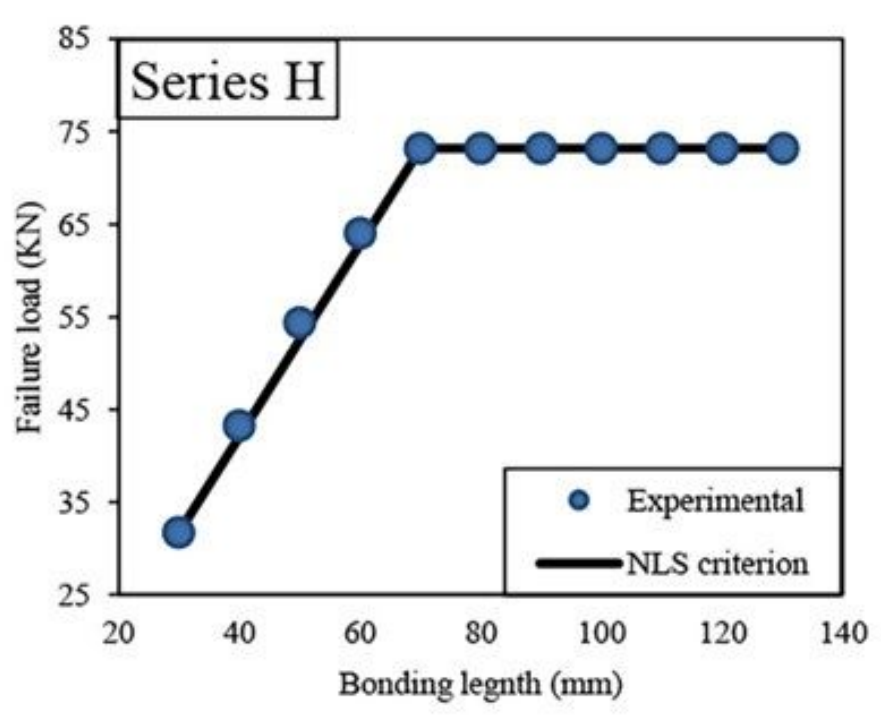

(d)

Figure 13

Comparison between the experimental failure loads of Double Strap Joints and the theoretical predictions obtained by means of NLS method; (a) series E; (b) series F; (c) series G; (d) series H. 